\title{
Joanna Bielecka-Prus
}

Uniwersytet Marii Curie-Skłodowskiej

https://doi.org/10.18778/1733-8069.9.1.08

\section{Anna Horolets}

Szkoła Wyższa Psychologii Społecznej w Warszawie

\section{Rekonstrukcja praktyk analizy dyskursu na podstawie wybranych anglojęzycznych czasopism dyskursywnych}

Abstrakt Artykuł ma cel eksploracyjny. Podjęto w nim próbę zrekonstruowania praktyk analizy dyskursu na podstawie badania zawartości abstraktów czasopism anglojęzycznych z zakresu analizy dyskursu („Language in Society”, „Discourse Studies”, „Discourse and Society”, „Language and Communication”, „Text and Talk”). Analizie poddano czasopisma mające wysoki współczynnik cytowalności i w związku z tym duży wpływ na wyznaczanie głównych trendów metodologicznych w analizie dyskursu. Obliczono częstotliwość występowania typów materiału badawczego (np. dyskurs ustny i mówiony) i przedmiotu analizy (interakcja instytucjonalna, codzienna, medialna i internetowa) oraz podejść teoretycznych i kategorii badawczych. Na podstawie szczegółowej analizy zróżnicowania pomiędzy czasopismami i tendencji wspólnych dla nich wszystkich dokonano wstępnych uogólnień na temat praktyk analizy dyskursu w krajach anglosaskich. Cechy wyróżniające te praktyki to między innymi skupienie się na interakcji, zainteresowanie kontekstami instytucjonalnymi i komunikacją mówioną oraz uprawianie badań stosowanych.

Słowa kluczowe analiza dyskursu, praktyki badawcze, czasopisma recenzowane, streszczenia, materiał badawczy, przedmiot analizy, podejścia teoretyczne, metody, kategorie analityczne

Joanna Bielecka-Prus, dr, adiunkt w Instytucie Socjologii UMCS. Jej zainteresowania badawcze koncentrują się wokół problematyki badań jakościowych i wykorzystywania tych metod $\mathrm{w}$ badaniach terenowych nad wykluczeniem społecznym, marginalizacją społeczną, obcością i tożsamością społeczną. Jest autorką książki Transmisja kultury w rodzinie i $w$ szkole. Teoria Basila Bernsteina (2010).

Dane adresowe autorki:

Instytut Socjologii

Wydział Filozofii i Socjologii UMCS

ul. Langiewicza 6a, pokój 18

e-mail: prus@pronet.lublin.pl
Anna Horolets, dr, pracuje w Szkole Wyższej Psychologii Społecznej w Warszawie. Zajmuje się badaniami dyskursywnych mechanizmów tworzenia światów społecznych i tożsamości oraz rolą słowa w budowaniu relacji władzy i podporządkowania. $W$ kręgu jej zainteresowań znajdują się teorie czasu wolnego, turystyki i migracji, prowadzi badania o turystyce niszowej do krajów byłego ZSRR oraz o czasie wolnym migrantów. Jest redaktorką pracy zbiorowej Analiza dyskursu w socjologii i dla socjologii (2008).

Dane adresowe autorki:

Szkoła Wyższa Psychologii Społecznej

ul. Chodakowska 19/31, 03-815 Warszawa e-mail: ahorolets@swps.edu.pl rtykuł jest rodzajem eksperymentu, w któ- $r y m$ postanowiłyśmy przeanalizować zawartość abstraktów czasopism anglojęzycznych z zakresu analizy dyskursu w celu zrekonstruowania praktyk analizy dyskursu (AD)

Mimo rozbieżnych ocen normatywnych tego stanu rzeczy recenzowane czasopisma są we współczesnej nauce jedną z najbardziej wpływowych instytucji, gdzie w sposób charakterystyczny dla społeczeństw poprzemysłowych następuje „koncentracja władzy bez jej centralizacji” (Sennet 2006). Czasopisma są odźwiernym do zdobycia pozycji akademickiej w myśl hasła „publish or perish”. Swój sukces zawdzięczają położeniu nacisku na wydajność akademicką we współczesnej nauce. Są one cenionym "miejscem" (lieu) do ogłaszania wyników badań lub idei teoretycznych, głównym źródłem instytucjonalnych wskaźników poczytności. Czasopismo pozwala na „zastrzeżenie” praw autorskich do pomysłów i kierunków badawczych (szerzej nt. roli czasopism w nauce zob. Pękala 2009). Czasopisma uczestniczą w gospodarce akademickiej w sensie przenośnym - jako jedna z ważnych instytucji, z którą naukowcy maja do czynienia, jeśli chcą osiągnąc sukces zawodowy. W dużej części czasopisma są bytami rynkowymi także w sensie dosłownym, jako przedsiębiorstwa rynkowe, „komórki" dużych koncernów wydawniczych ${ }^{1}$.

Biorąc pod uwagę rolę czasopism $\mathrm{w}$ strukturze współczesnej nauki i ich wagę, stwierdziłyśmy, że zbadanie zawartości czasopism dyskursywnych jest jednym ze sposobów na prześledzenie tego, ja-

$42 \%$ wszystkich ukazujaccych się w czasopismach artykułów ukazało się $\mathrm{w}$ czasopismach należących do jednego $\mathrm{z}$ trzech najwiekkszych koncernow wydawniczych: Elsevier, Springer i WileyBlackwell (Jha 2012). Beedac spótkami, giełdowymi, ktorych roczne e wydaja 1500-2000 tytutów czasopism i od kilku do 20 tysiecy ksiazzek rocznie. Mniejsze wydawnictwa, np. Sage lub Routledge, są wydawcami 600-650 tytưów. Informację zaczerpnięto ze stron internetowych tych wydawnictw, a ponieważ największe z nich sa kie teorie i metody badań zostają usankcjonowane poprzez ogłoszenie drukiem. Zakładamy, że wybór redaktorów i recenzentów czasopism przez nas analizowanych jest jednocześnie praktyką uprawomocnienia pewnego kształtu (sub)dyscypliny analizy dyskursu przez osoby mające duży wpływ w polu naukowym. Artykuł ten ma cel eksploracyjny i przeglądowy. Interesują nas zależności między wyborem przedmiotu analizy lub materiału empirycznego a wyborem orientacji teoretycznej. Chcemy stworzyć mapę praktyk analizy dyskursu, na której widoczne będą powiązania między kategoriami analitycznymi a teoriami i metodami $\mathrm{AD}$.

Badane czasopisma

W wyborze czasopism kierowałyśmy się kryteriami siły oddziaływania, rozpoznawalności, renomy i stabilności czasopisma. Użyłyśmy kryteriów obiektywnych (do próby włączyłyśmy czasopisma o najwyższych wskaźnikach cytowalności i regularnie wydawane) oraz subiektywnych (np. określając renomę czasopisma, brałyśmy pod uwagę naszą wiedzę o wiodących zachodnich autorach w zakresie analizy dyskursu; stwierdziłyśmy także, że interesują nas czasopisma prawdziwie międzynarodowe, to jest mające rady redakcyjne i redakcje złożone z przedstawicieli co najmniej kilku krajów)2. Do próby włączyłyśmy abstrakty czasopism, począwszy od ostatnich dwóch (lub trzech w przypadku dwumiesięczników) numerów z 2007 roku aż po wszystkie numery opublikowane do czerwca 2012. W ten sposób analizą objęłyśmy pełne pięć lat. W sumie dokonano analizy zawartości 727 streszczeń artykułów ze 134 numerów.

${ }^{2}$ Łączne zastosowanie tych kryteriów spowodowało odrzucenie przez nas czasopisma „Discourse Processes", które miało naj wyższy IF, ale objętość numerów wahała się od 3 do 8 artykułów; dodatkowo nie rozpoznałyśmy ani jednego nazwiska członków rady redakcyjnej i redakcji, a wszyscy oni mieli afiliację uniwer-
sytetów amerykańskich. 
Tabela 1. Liczba zbadanych numerów i abstraktów.

\begin{tabular}{|c|c|c|}
\hline Tytuł czasopisma & Liczba numerów & Liczba abstraktów artykułów \\
\hline "Language in Society" (LiS) & 25 & 102 \\
\hline "Discourse Studies” (DS) & 29 & 163 \\
\hline "Discourse and Society" (D\&S) & 30 & 156 \\
\hline "Language \& Communication” (L\&C) & 21 & 132 \\
\hline "Text and Talk” (T\&T) & 29 & 174 \\
\hline SUMA & $\mathbf{1 3 4}$ & $\mathbf{7 2 7}$ \\
\hline
\end{tabular}

Źródło: opracowanie własne

Wybrałyśmy metodę analizy treści, starając się stworzyć reprezentatywny portret kilku cech pięciu wybranych czasopism (materiał i przedmiot analizy, wykorzystywane teorie i kategorie badawcze). Obliczenie częstotliwości używania określonych kategorii analizy lub podejść teoretycznych jest naszym zdaniem niezbędną pracą początkową, która pozwala przejść do lepszego zrozumienia praktyk badawczych AD.

Interpretacji uzyskanych danych dokonujemy, lokując je w bezpośrednim kontekście tekstowym ich pojawiania się (co-text) i zestawiając $z$ innymi tekstami z całego zbioru i informacją o źródle ${ }^{3}$. Mamy nadzieję, że w ten sposób badaniu bazującemu na metodzie analizy treści nadajemy refleksyjność dyskursywną.

${ }^{3}$ Kontekst językowy (co-text) to tekst bezpośrednio poprzedzajaccy i następujacy po analizowanym wyrazie, fragmencie lub kie mowy, jest to kontekst lingwistyczny.

\section{Charakterystyka czasopism}

Tabela 2. Dane wydawnicze badanych czasopism.

\begin{tabular}{|c|c|c|c|c|}
\hline $\begin{array}{c}\text { Tytuł } \\
\text { czasopisma }\end{array}$ & $\begin{array}{c}\text { IF } \\
\mathbf{2 0 1 1}\end{array}$ & Wydawca & $\begin{array}{c}\text { Rok wydania } \\
\text { pierwszego numeru }\end{array}$ & Redaktor naczelny \\
\hline LiS & 1,189 & Cambridge Univeristy Press & 1972 & Barbara Johnstone (USA) \\
\hline DS & 0,787 & SAGE & 1999 & Teun A. van Dijk (Hiszpania) \\
\hline D\&S & 0,672 & SAGE & 1990 & Teun A. van Dijk (Hiszpania) \\
\hline L\&C & 0,667 & Elsevier & 1981 & $\begin{array}{c}\text { Talbot Tylor (USA) } \\
\text { i John E. Joseph (UK) }\end{array}$ \\
\hline T\&T & 0,493 & De Gruyter Mouton & 1981 & Srikant Sarangi (UK) \\
\hline
\end{tabular}

Źródło: opracowanie własne
"Language in Society" (LiS) publikuje analizy z zakresu badań nad językiem i dyskursem w obszarze socjolingwistyki, antropologii lingwistycznej oraz pokrewnych im dyscyplin naukowych. Rada wydawnicza czasopisma składa się z 28 osób, głównie z USA (15 osób), Wielkiej Brytanii (6 osób) i Kanady (3 osoby). Do rady naukowej czasopisma należą między innymi: Deborah Tannen, Jan Blommaert, Alessandro Duranti i Ruth Wodak.

"Discourse Studies" (DS) publikuje prace międzydyscyplinarne $\mathrm{z}$ zakresu językoznawstwa, antropologii, etnometodologii, psychologii kognitywnej i społecznej, prasoznawstwa, jak również $\mathrm{z}$ badań nad komunikowaniem. $\mathrm{W}$ radzie naukowej jest 51 osób, przede wszystkim z USA (24), ale także Wielkiej Brytanii (8), Holandii (3), Niemiec, Francji, Australii i Izraela (po 2 osoby), wśród nich są: Malcolm Coulthard, Emanuel Schegloff, Deborah Schiffrin i Paul ten Have.

"Discourse and Society" (D\&S) publikuje prace z pogranicza studiów dyskursowych (discourse studies) i nauk społecznych. Redakcja, rada honorowa i rada doradcza czasopisma liczą w sumie 51 osób, w tym głównie z Wielkiej Brytanii (16), USA (13), Australii (3) oraz Niemiec, Chin, Hiszpanii (po 2 przedstawicieli). $\mathrm{W}$ tych radach uczestniczą między innymi: Aaron Cicourel, Noam Chomsky, Stuart Hall, Michael Halliday i Norman Fairclough.

„Language \& Communication" (L\&C) specjalizuje się $\mathrm{w}$ interdyscyplinarnych analizach języka $i$ komunikacji prowadzonych $w$ ramach wielu dyscyplin naukowych (m.in. językoznawstwa, analizy dyskursu, filozofii i antropologii języka, socjolingwistyki). Rada wydawnicza składa się z 19 osób, głównie to reprezentanci USA (7), Wielkiej Brytanii (3) i Holandii (2). W skład rady wchodzą mię- dzy innymi Asif Agha, Jan Blommaert i Michael Silverstein.

„Text and Talk. An Interdisciplinary Journal of Language, Discourse \& Communication Studies" (T\&T) w autoopisie podkreśla, że celem pisma jest autorefleksja nad stanem (sub)dyscypliny, którą redaktorzy określają jako „badania języka i komunikowania" (language and communication research). W skład redakcji oraz rad wchodzi 51 osób, w redakcji i radzie specjalistycznej są tylko naukowcy z USA i Wielkiej Brytanii, wśród nich między innymi: Malcolm Coulthard, Gunther Kress, John Gumperz, Michael Stubbs i Margaret Wetherell.

Wyliczenie krajów, w których pracują członkowie redakcji i rad wszystkich pięciu czasopism razem wziętych, pokazuje dość wyraźną przewagę dwóch państw: Stanów Zjednoczonych (77 osób na 196, 40\%) i Wielkiej Brytanii (48 osób na 196, 24\%). Pozostałe kraje są reprezentowane przez kilkakrotnie mniejszą liczbę osób, na przykład: Australia (8), Holandia i Niemcy (po 7), Chiny (6), a większość krajów, w tym jeden kraj środkowoeuropejski (Czechy), pojawia się tylko raz. Nieobecne są kraje arabskie i Rosja.

Jednak nie tylko geografia, a przynajmniej nie tylko geografia, rozumiana jako kraj afiliacji akademickiej redaktorów i członków rad czasopism, może odgrywać rolę $\mathrm{w}$ promowaniu czasopisma na pozycję bardziej lub mniej wpływowego (ściślej: mającego wysoki IF). Wysoki IF czasopisma LiS jest najprawdopodobniej pochodną tego, że w odróżnieniu od innych czasopism, rozwijających stosunkowo nową subdyscyplinę (discourse studies), LiS jest zakorzenione w tradycji amerykańskiej antropologii lingwistycznej (czyli jednego z czterech 
pól wchodzących w skład antropologii amerykańskiej jako dyscypliny: antropologii językowej, archeologii, antropologii fizycznej i antropologii kulturowej [por. Barth i in. 2007: 287 i nast.]) i ma solidne dyscyplinarne i profesjonalne ugruntowanie.

Wreszcie stwierdzić można, że pole studiów dyskursywnych jest stosunkowo wąskie, mimo że szybko się rozwija. Świadczy o tym choćby fakt,

że kilka osób udziela się w charakterze członka redakcji lub członka rady nie w jednym, lecz w kilku badanych czasopismach (np. Ruth Wodak, Deborah Tannen, Jan Blommaert).

\section{Geograficzna dystrybucja autorów}

Czasopisma różnią się nie tylko specyfiką tematyczną i składem rad wydawniczych, ale także odsetkiem autorów artykułów z krajów anglojęzycznych.

Tabela 3. Geograficzna dystrybucja rad redakcyjnych i autorów artykułów.

\begin{tabular}{|c|c|c|c|c|}
\hline $\begin{array}{c}\text { Tytuł } \\
\text { czasopisma }\end{array}$ & IF & $\begin{array}{c}\text { \% artykułów z krajów } \\
\text { anglojęzycznych }\end{array}$ & $\begin{array}{c}\text { afiliacja redaktora/ów } \\
\text { naczelnych }\end{array}$ & $\begin{array}{c}\text { \% osób z krajów } \\
\text { anglojęzycznych w radach }\end{array}$ \\
\hline LiS & 1,189 & 86 & USA & 89 \\
\hline DS & 0,787 & 55 & Hiszpania & 67 \\
\hline D\&S & 0,672 & 64 & Hiszpania & 67 \\
\hline L\&C & 0,667 & 76,5 & USA, UK & 58 \\
\hline T\&T & 0,493 & 54,5 & UK & 72,5 \\
\hline
\end{tabular}

Źródło: opracowanie własne

Stwierdzenie dominacji naukowców z USA i Wielkiej Brytanii wśród redaktorów i autorów zachodnich czasopism dyskursywnych nie jest niczym odkrywczym. W czasopismach, w których redaktor naczelny reprezentuje uniwersytet europejski, liczba tekstów z krajów anglojęzycznych stanowi prawie 50\% wszystkich publikowanych tekstów. Natomiast w przypadku czasopism, w których redaktor naczelny afiliowany jest przy uniwersytecie amerykańskim, zdecydowanie dominują teksty z USA. Czy wynika z tego, że Europejczycy są bardziej otwarci? Czy raczej, że same Stany Zjednoczone oferują tak szeroki rynek czytelniczy, że redaktorzy nie dążą nawet do przyciągania autorów skądkolwiek indziej lub nie są skłon- ni przymykać oka na (zazwyczaj) mniejsze językowe kompetencje autorów nieanglojęzycznych? „Geografia" rad i autorów przywodzi na myśl także dziedzictwo kolonialne: metropolie zarządzają niejako dostępem peryferii do cennych zasobów - w tym przypadku możliwości publikowania - rezerwując sobie jednak taką przewagę, która pozwala zawsze wyprzedzić konkurencję To także częściowo mogłoby tłumaczyć bardzo słabą obecność Irlandii i Kanady, choć inne czynniki niż dostęp (np. brak zainteresowania analizą dyskursu, preferencja dla szerzej zakrojonych analiz komunikowania itd.) mogą decydować o ich skromnej reprezentacji w badanych czasopismach. Postkolonialne tło ma także zauważona

przez nas praktyka LiS: wiele artykułów w tym czasopiśmie dotyczy komunikowania $\mathrm{w}$ językach małych społeczności etnicznych, na przykład języka Aborygenów australijskich, Indian Navajo, Arawaków, ludów posługujących się językiem senegalskim, dialektami arabskimi czy chińskimi bądź tureckimi, ale są one najczęściej przedmiotem badań językoznawców z USA.

\section{Rodzaj materiału empirycznego}

Zaskakującym wynikiem okazała się zdecydowana przewaga analiz języka mówionego nad pisanym. Tabela poniżej przedstawia, ile artykułów poświęconych językowi mówionemu przypada na jeden artykuł poświęcony językowi pisanemu w badanych czasopismach.

Tabela 4. Proporcjonalny rozkład materiału pisanego do mówionego w badanych czasopismach

\begin{tabular}{|c|c|c|c|c|c|}
\hline & LiS & DS & D\&S & L\&C & T\&T \\
\hline pisany & 1 & 1 & 1 & 1 & 1 \\
\hline mówiony & 7,5 & 2,2 & 1,4 & 2,5 & 2,2 \\
\hline
\end{tabular}

Źródło: opracowanie własne

Oprócz artykułów, w których materiałem analizy jest osobno język mówiony lub pisany, w części tekstów materiał pisany i mówiony są zestawiane i porównywane: w T\&T i D\&S jest po około 10 tekstów tego typu. Pojawiają się także analizy łączące analizę mowy i danych wizualnych (w DS 17, w LiS 5, w L\&C 5), są to przede wszystkim dane pochodzące z nagrań wideo, poddawane analizie $\mathrm{z}$ użyciem ramy teoretyczno-metodologicznej analizy konwersacyjnej.

Tekstów opartych na danych wyłącznie wizualnych jest niewiele: $1 \mathrm{w}$ DS oraz $4 \mathrm{w}$ LiS, $\mathrm{w}$ tym trzy dotyczą języka migowego, a w L\&C tekst bazujący na danych wizualnych dotyczy sztuki w przestrzeni miejskiej. W wyjątkowych przypadkach materiałem analizy nie był język naturalny, lecz inne praktyki komunikowania: ruchy ciała (gesty) lub język ciała, architektura i przestrzeń fizyczna, a nawet transakcje finansowe (autorzy przedstawili globalne rynki finansowe jako system komunikacyjny). Być może wynika to z nie do końca rozstrzygnięte- go statusu reprezentacji wizualnych (czy możemy mówić o języku w przypadku przekazów wizualnych, czy też raczej jest to jedyne metafora?). Inną przyczyną może być brak odpowiedniego aparatu analitycznego, który przystosowany jest do analiz przekazu werbalnego. Być może także znacznie trudnej powiązać przekazy wizualne z praktykami społecznymi (por. Rose 2010).

W obu czasopismach były także teksty, dla których na podstawie abstraktu nie można było jednoznacznie określić rodzaju materiału empirycznego (L\&C: 18; T\&T: 15; LiS: 8; D\&S: 3; DS: 1). Nie zawierały one opisu próby badawczej lub materiał był określony ogólnikowo - jako „korpus (językowy)”. Były także takie, w których trudno było wywnioskować, czy i jaki jest wykorzystywany w danym tekście rodzaj materiału empirycznego.

Oprócz artykułów zawierających analizy empiryczne $\mathrm{w}$ badanych czasopismach publikowane są także artykuły teoretyczne i metodologiczne, 
w których rodzaj materiału albo nie jest w ogóle wskazywany, albo stanowi jedynie tło dla pytań teoretycznych i metodologicznych stawianych przez autorów. Najwięcej takich artykułów znajduje się w L\&C (40) i dotyczą one takich obszarów tematycznych, jak teorie języka (retoryka, filozofia języka), analizy diachroniczne, polityka językowa, dialektologia, lingwistyka ewolucyjna (komunikowanie się małp). W tym czasopiśmie jest także numer poświęcony etycznym zagadnieniom badań nad językiem: kwestiom tworzenia archiwów danych oraz relacji badacza z badanymi. W DS (20 artykułów) mamy rozważania metodologiczne na temat problemu transkrypcji danych, związków zachodzących między hermeneutyką a analizą dyskursu oraz teoretycznych powiązań krytycznej analizy dyskursu (KAD) z innymi dyscyplinami nauki. W T\&T (18 artykułów) poruszane są takie tematy, jak metodologia (np. etnografia jako metoda badań dyskursywnych) lub koncepcje teoretyczne z zakresu narratologii, tekstologii, opublikowano również teksty poświęcone kategoriom niezrozumiałości (unintelligibility). W D\&S artykułów o teoretyczno-metodologicznej tematyce jest mniej (7), głównie metarefleksje nad praktyką badawczą w studiach nad dyskursem. Najmniej tego typu artykułów znalazłyśmy w LiS (2) i są to analizy diachroniczne.

Osobną kategorię stanowią teksty z numerów tematycznych poświęconych teoretykom $\mathrm{AD}$ lub wybranym koncepcjom (jest to przypadek tylko T\&T). Były to między innymi teksty na temat Aarona Cicourela i jego dorobku w zakresie wiedzy, autentyczności, poznania; kategorii niezrozumiałości (unintelligibility) i tego, jak uczestnicy praktyk religijnych tworzą lub wydobywają z nich sens; Della Hymesa i etnografii czy antropologii komuniko- wania, ze szczególnym uwzględnieniem problematyki ethnopoesis; Johna Gumperza i antropologii, przełączania kodów, indeksykalności i tak dalej. Te teksty same są rodzajem metadyskursu instytucjonalnego: budują AD jako dyscyplinę, wnoszą wkład w jej instytucjonalizację poprzez wyznaczenie „tekstów pierwszych” $i$ istotnych kategorii.

Warto zwrócić uwagę na to, że badane czasopisma AD są autorefleksyjne. $W$ tym względzie szczególnie interesująca jest wymiana w D\&S między Michaelem Billigiem, Teunem A. van Dijkiem (redaktorem naczelnym tego czasopisma) i kilkoma innymi badaczami: Billig atakuje KAD za to, że grzeszy „strategiami nazywania”, które krytykuje (tworzenie podziału „dobrzy my” - „źli oni”). W badanym materiale podobnych tekstów krytycznych jest kilkanaście: przykładowo, w jednym z artykułów analizuje się, jak działa analityk konwersacyjny, w innym jeszcze - jak słyszący badacz zbiera materiał od niedosłyszących badanych i tak dalej. Tworzy to kontrast z polską praktyką, w której teksty poddające samą AD krytycznej refleksji są rzadkie (por. Zarycki 2012).

Opis przedstawiony powyżej wywołuje kilka pytań i refleksji. Zanim do nich przejdziemy, chciałybyśmy wyeksplikować, że traktujemy badane przez nas czasopisma o wysokiej cytowalności jako „odźwiernych” w polu naukowym, którzy wpływają na sposoby uprawiania analizy dyskursu, promując lub ignorując pewne podejścia teoretyczne i metodologiczne. Dlatego wychodzimy z założenia, że badane przez nas cechy czasopism są stosunkowo reprezentatywnym obrazem praktyk analizy dyskursu w krajach zachodnich.

Znacząca przewaga ilościowa badań języka mówionego nad badaniami języka pisanego sygnalizuje, że praktyka badawcza analityków dyskursu publikujących w czołowych periodykach anglojęzycznych nie jest wyłącznie, ani nawet przede wszystkim, obcowaniem z tekstem. Jak można wyjaśnić tę przewagę? Jedną z przyczyn może być wpływ preferencji teoretycznych, a nawet ideologicznych na wybór materiału empirycznego. Przykładowo, preferencja dla teorii podkreślających istotność działania i akcentujących rolę aktora społecznego w tworzeniu rzeczywistości społecznej może być łatwiej „wspierana” przez przykłady z interakcji mówionej4. Po drugie, może to być wpływ imperatywu przejrzystości metodologicznej na proces badawczy: wybór materiału mówionego pozwala na dość precyzyjne określenie kontekstu interakcji oraz kontrolę jego elementów składowych, co sprawia, że kontekst jest bardziej „kompaktowy” niż w przypadku tekstów pisanych. Wreszcie, wpływ na preferencje dla tekstów mówionych może mieć kontekst instytucjonalny badań. To przypuszczenie pośrednio potwierdza wybór terenu badań, którym bardzo często są różnego typu instytucje. Zakładając, że procesy komunikowania formalnego i nieformalnego wpływają na sposób funkcjonowania instytucji, badanie procesu semiozy ma wymiar nie tylko poznawczy, ale i praktyczny.

Praktyki badawcze autorów (zachodnich) przypominają praktyki socjologów jakościowych lub antropologów, a nie lingwistów i literaturoznawców ( $\mathrm{w}$ tradycyjnym pojmowaniu praktyki badawczej tych dyscyplin). Taki charakter praktyki badawczej pociąga za sobą kilka konsekwencji. Po pierwsze, bardziej istotne stają się kwestie etyczne, takie jak nierówna pozycja władzy między badanymi i badaczem, uzyskiwanie świadomej zgody bada-

${ }^{4}$ Za tę sugestię jesteśmy wdzięczne jednemu z anonimowych recenzentów naszego artykułu. nych na nagrywanie ich rozmów lub zachowanie poufności uzyskanych danych. Po drugie, w wyniku konieczności kontaktu z instytucjami i uzyskania pozwoleń na prowadzenie badań powstaje rodzaj zależności badacza od terenu badawczego, który jest dobrze znany na przykład antropologom organizacji. Po trzecie, pociaga to za sobą pewne skutki metodologiczne: język mówiony wymaga transkrypcji, więc w swoich analizach badacz ma do czynienia z przetworzonym materiałem badawczym, który w wyniku obróbki może tracić część swoich właściwości - i nabywać nowych. Sama sytuacja nagrywania wywiera ponadto jakiś wpływ na treść i formę rozmowy (za wyjątkiem nagrywania z ukrycia).

Interesującą cechą wyboru rodzaju materiału badawczego jest dość zauważalna obecność artykułów korzystających z dwóch albo więcej rodzajów danych (ustny i pisany; ustny i wizualny; pisany i wizualny lub wszystkie trzy w połączeniu). $Z$ jednej strony zdradza to tendencję do multimodalności analiz dyskursywnych, która świadczy o pojmowaniu komunikowania jako złożonego procesu odbywającego się różnymi kanałami komunikacyjnymi oraz o rozwoju technologii zaangażowanych w produkcję i rejestrację komunikacji. Z drugiej strony jest to swoisty znak wysokiej świadomości metodologicznej charakteryzującej autorów: testują oni, czy interesujące ich cechy językowe "pracują" inaczej $\mathrm{w}$ zależności od rodzaju materiału badawczego, co pozwala także na mające większe znaczenie socjologiczne wnioski z analiz. Przykładowo, w artykule o użyciu słów tara i to (partykuły łączące części zdania, pokazujące niespodziewane skutki w języku japońskim) autor zestawia mowę i pismo, by pokazać, że jedno ze słów jest częściej używane w piśmie, drugie - $\mathrm{w}$ mowie (choć są jednoznaczne), a użycie 
jednego albo drugiego tworzy nieco odmienne formy suspensu w narracji, przy czym kluczowa jest obecność/nieobecność odbiorcy komunikatu.

\section{Przedmiot badań}

Kolejną cechą, którą uznałyśmy za istotną dla praktyk badawczych studiów nad dyskursem, są

preferencje dla poszczególnych typów przedmiotu badań i konkretne wybory tematyczne. Zdając sobie sprawę z niedoskonałości takiego podziału, wyróżniłyśmy cztery kategorie (komunikacja codzienna, media, Internet, komunikacja instytucjonalna) i sprawdziłyśmy dystrybucję tych kategorii w badanych czasopismach.

Tabela 5. Przedmiot badań $\mathrm{w}$ badanych czasopismach.

\begin{tabular}{|c|c|c|c|c|c|c|c|c|c|c|}
\hline $\begin{array}{c}\text { Tytuł } \\
\text { czasopisma }\end{array}$ & \multicolumn{2}{|c|}{ Codzienna } & \multicolumn{2}{|c|}{ Media } & \multicolumn{2}{c|}{ Internet } & \multicolumn{2}{|c|}{ Instytucjonalna } & \multicolumn{2}{|c|}{$\begin{array}{c}\text { Ogólna liczba abstraktów } \\
\text { empirycznych w czasopiśmie }\end{array}$} \\
\hline & $N$ & $\%$ & $N$ & $\%$ & $N$ & $\%$ & $N$ & $\%$ & $\mathbf{N}$ & $\%$ \\
\hline LiS & 45 & 7,2 & 7 & 1,1 & 3 & 0,5 & 35 & 5,6 & 90 & 14,5 \\
\hline DS & 36 & 5,8 & 19 & 3,1 & 13 & 2,1 & 62 & 10,0 & 130 & 20,9 \\
\hline D\&S & 32 & 5,2 & 33 & 5,3 & 8 & 1,3 & 82 & 13,2 & 155 & 25,0 \\
\hline L\&C & 27 & 4,3 & 18 & 2,9 & 8 & 1,3 & 27 & 4,3 & 80 & 12,9 \\
\hline T\&T & 24 & 3,9 & 25 & 4,0 & 7 & 1,1 & 110 & 17,7 & 166 & 26,7 \\
\hline Suma & $\mathbf{1 6 4}$ & $\mathbf{2 6 , 4}$ & $\mathbf{1 0 2}$ & $\mathbf{1 6 , 4}$ & $\mathbf{3 9}$ & $\mathbf{6 , 3}$ & $\mathbf{3 1 6}$ & $\mathbf{5 0 , 9}$ & $\mathbf{6 2 1}$ & $\mathbf{1 0 0 , 0}$ \\
\hline
\end{tabular}

Źródło: opracowanie własne

W ramach każdej z tych czterech kategorii starałyśmy się zarejestrować konkretną problematykę badań. Wyniki tych starań przedstawiamy w czterech porównawczych opisach poniżej, zaczynając od komunikacji instytucjonalnej jako najbardziej popularnego przedmiotu badań dyskursywnych $\mathrm{w}$ analizowanych czasopismach.

\section{Komunikacja instytucjonalna}

Znacząca przewaga komunikowania instytucjonalnego - najczęściej wybieranego przedmiotu analiz w badanych czasopismach - była dla nas zaskocze- niem. Wprawdzie określiłyśmy tę kategorię szeroko, zaliczając do niej także przykłady komunikacji politycznej (debat w parlamencie, przemówień prezydenta, kampanii wyborczej itd.), ale to wydaje się nam uzasadnione. Biorąc pod uwagę to, że przedmiotem analiz czyniono materiały z przesłuchań policyjnych, grup terapeutycznych i tak dalej (tzw. sensitive material), interesująca w przypadku tej kategorii jest także kwestia dostępu do danych. Co więcej, częste zwracanie się do komunikacji instytucjonalnej $\mathrm{w}$ analizach można traktować jako świadectwo specyfiki analizy dyskursu jako praktyki akademickiej w świecie anglosaskim: czy jest bardziej uznana niż w Polsce, czy jest wyraźniej skierowana na praktykę społeczną, używana jako badania stosowane?

W ramach komunikacji instytucjonalnej pojawia się kilka kontekstów: biznesowy, akade-

micki, edukacyjny, terapeutyczny, prawniczy, polityczny, religijny i inne. Przedstawiłyśmy ich dystrybucję $\mathrm{w}$ tabeli, żeby pokazać, że czasopisma mają specyficzne ukierunkowanie $\mathrm{w}$ ramach szeroko pojętej problematyki instytucjonalnej.

Tabela 6. Rodzaje dyskursu instytucjonalnego w badanych czasopismach.

\begin{tabular}{|c|c|c|c|c|c|c|c|c|}
\hline & 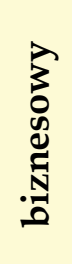 & 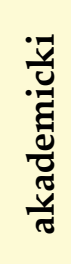 & 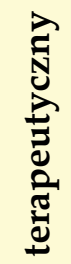 & 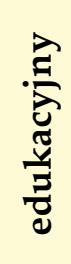 & 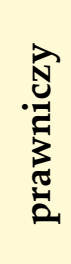 & 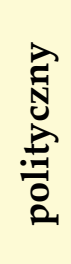 & 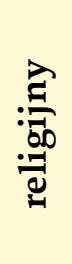 & . \\
\hline LiS & 10 & 9 & 4 & 3 & 1 & 5 & 2 & 1 \\
\hline DS & 16 & 15 & 12 & 11 & 4 & 2 & 0 & 2 \\
\hline D\&S & 3 & 6 & 5 & 6 & 11 & 36 & 1 & 14 \\
\hline L\&C & 5 & 4 & 5 & 4 & 1 & 4 & 4 & 0 \\
\hline $\mathrm{T} \& \mathrm{~T}$ & 20 & 7 & 9 & 15 & 12 & 8 & 10 & 29 \\
\hline Suma & 51 & 41 & 35 & 39 & 29 & 56 & 16 & 46 \\
\hline
\end{tabular}

Źródło: opracowanie własne

W DS najwięcej jest tekstów z obszaru biznesu/pracy (16), w tym 5 z zebrań pracowników, 3 z rozmów telefonicznych. Kolejną dużą grupą jest dyskurs akademicki (15) - teksty dotyczą głównie komunikowania w procesie zbierania danych, na przykład eksperymentów, wywiadów, kodowania (8), ale pojawiają się także analizy naukowych abstraktów, artykułów i czasopism (4) oraz wykładów i prezentacji (3). 12 artykułów dotyczy dyskursu terapeutycznego, tu najliczniej przedstawiony jest dyskurs psychiatryczny i praca socjalna (9). W tekstach dotyczących dyskursu edukacyjnego (11) przeważają analizy komunikowania w klasie szkolnej (5). Dyskurs prawniczy (4) to przesłuchania, najsłabiej reprezentowany jest zaś polityczny (2).
Podobne rozłożenie akcentów zaobserwowałyśmy także w czasopiśmie LiS. Wśród tekstów dotyczących dyskursu instytucjonalnego przeważa dyskurs biznesu/pracy (10), na przykład analiza pism urzędowych, zebrań, rozmów z klientem. Następnie dyskurs akademicki (9), tu głównie analiza komunikowania w trakcie badań (wywiady, narracje). Dyskurs polityczny reprezentuje 5 tekstów (np. analiza zebrań, przemówień), pozostałe podtypy są mniej licznie reprezentowane.

W czasopiśmie L\&C nie ma wyraźnej przewagi jakiegoś typy dyskursu, wszystkie reprezentowane są przez 4-5 tekstów. Wyjątkiem jest dyskurs prawniczy analizowany tylko w 1 tekście. 
Do przewidzenia było to, że w D\&S dość silna będzie obecność tekstów politycznych (36) - jest to najbardziej liczna kategoria tekstów instytucjonalnych w tym czasopiśmie. Drugim najliczniejszym podtypem dyskursu instytucjonalnego w D\&S były teksty prawnicze, takie jak dokumenty prawne, transkrypcje posiedzeń sądów (11). Dyskursy terapeutyczny, edukacyjny, akademicki - wszystkie reprezentowane były przez 6-5 tekstów.

Inaczej rozłożone są akcenty w T\&T: najliczniejsza grupa tekstów poświęconych dyskursowi instytucjonalnemu dotyczy dyskursu biznesu i miejsca pracy (20), dalej plasują się dyskurs edukacyjny (15) i prawniczy (12), kolejnym analizowanym typem komunikacji instytucjonalnej jest komunikacja w instytucjach religijnych (10), najliczniej reprezentowany spośród wszystkich czasopism, dalej - dyskurs terapeutyczny (9) i dopiero po tym polityczny (8) i akademicki (7). Jednocześnie podkreślić należy, że na tle innych czasopism T\&T zawiera najwięcej tekstów dotyczących komunikacji instytucjonalnej, więc liczba tekstów poświęconych dyskursowi akademickiemu, przykładowo, porównywalna jest z LiS, gdzie dyskurs akademicki uplasował się na 2 miejscu.

W zależności od charakteru czasopisma w różnych podtypach dyskursu instytucjonalnego nierówności i relacje władzy są albo akcentowane (np. D\&S), albo poświęca się im stosunkowo niewiele uwagi (np. LiS). Sądzimy, że może to być przeważnie efekt korzystania z ramy analitycznej KAD-u w pierwszym $z$ nich, podczas gdy w drugim zdecydowanie przeważa podejście analizy socjolingwistycznej lub etnograficznej.

\section{Komunikacja codzienna}

W analizowanych czasopismach komunikacja codzienna stanowiła drugi najważniejszy przedmiot analiz. Zauważyłyśmy różnice między czasopismami $\mathrm{w}$ wyborze tematyki wewnątrz szeroko określonej kategorii „,komunikacja codzienna”.

W LiS niemal połowa to badania z zakresu etnolingwistyki, dotyczące zagadnień komunikowania w określonych społecznościach lokalnych, mniejszościach językowych czy problemów komunikowania między społecznościami, zmiany kodów. Także w L\&C artykuły poświęcone komunikacji codziennej dotyczyły przede wszystkim komunikowania $\mathrm{w}$ obrębie określonych grup etnicznych i społeczności językowych. Natomiast w DS najczęściej nie została wyraźnie określona sytuacja społeczna konwersacji, ale także można było zauważyć, że autorzy skupiali się w analizach na konwersacjach osób pełniących określone role społeczne (kobiety -2 , dzieci -5 oraz członkowie rodziny - 5). Rzadziej analizowane były także rozmowy telefoniczne (3 teksty). W D\&S większość tekstów bazujących na komunikowaniu codziennym dotyczyła tworzenia lub negocjowania tożsamości (etnicznej, rasowej, genderowej itd.). W T\&T zaobserwowałyśmy bardzo duży rozrzut tematyczny, ale charakterystyczną cechą było to, że aż 11 tekstów (na $24 \mathrm{w}$ tej kategorii) pochodziło z korpusów, nie z konkretnych/umiejscowionych rozmów.

\section{Komunikacja medialna}

Na trzecim miejscu uplasowała się komunikacja medialna. Wyłączając z kategorii komunikacji medialnej Internet jako medium pozwalające na dużo większe sprzężenie zwrotne i przekroczenie ograniczeń centralizacji, wyróżniłyśmy pięć podtypów tej kategorii - TV, prasa, radio, literatura i muzyka.

Tabela 7. Rodzaje dyskursu medialnego w badanych czasopismach.

\begin{tabular}{|c|c|c|c|c|c|}
\hline & TV & Prasa & Radio & Literatura & Muzyka \\
\hline LiS & 5 & 2 & 0 & 0 & 0 \\
\hline DS & 9 & 8 & 1 & 0 & 0 \\
\hline D\&S & 9 & 20 & 1 & 0 & 0 \\
\hline L\&C & 7 & 7 & 0 & 0 & 0 \\
\hline T\&T & 10 & 11 & 1 & 3 & 1 \\
\hline Suma & $\mathbf{4 0}$ & $\mathbf{4 8}$ & $\mathbf{3}$ & $\mathbf{3}$ & $\mathbf{1}$ \\
\hline
\end{tabular}

Źródło: opracowanie własne

Bardziej szczegółowa analiza konkretnych tematów pozwala dostrzec zarówno tendencje wspólne wszystkim czasopismom (np. poświęcenie uwagi problemowi reprezentacji), jak i różnicujące je cechy. Różnice między czasopismami są wynikiem ich specjalizacji tematycznej i częściowo podejścia teoretycznego. A zatem w D\&S, akcentującym istotność podejścia krytycznego, w tekstach dotyczących mediów najwięcej uwagi poświęca się problemom społecznym. W sumie 12 z 32 tekstów poświęconych jest problemom społecznym, a konkretnie: migracji (4), rasizmowi (5), ekologii, energii nuklearnej, SARS. Kolejny zespół problemów to dyskusje polityczne (10) oraz genderowe. Repertuar problemów społecznych skłania do utożsamienia agendy D\&S z agendami nowych ruchów społecznych i kwestiami znajdującymi poparcie/ rozgłos wśród nowej klasy średniej, choć także dość znaczna jest obecność dyskursu politycznego, a więc zainteresowanie władzą i jej sprawowaniem, charakterystyczne dla tradycyjnych ruchów społecznych. Stosunkowo mało jest artykułów o biedzie i nierównościach ekonomicznych.

Podobne tendencje zaobserwować można w DS. W 19 tekstach, w których przedmiotem badawczym były media, analizy dotyczyły strategii dys- kursywnych w danym gatunku dziennikarskim, a także strategii retorycznych kształtujących opinie publiczną na temat jakichś ważnych wydarzeń. W L\&C tematyka artykułów poświęconych mediom oscylowała wokół gatunków lub reprezentacji wydarzeń.

Natomiast specyfika tematyczna czasopisma LiS przesądziła o tym, że w 7 artykułach poświęconych mediom dominuje nastawienie na analizę wielokulturowości $\mathbf{w}$ mediach: polityki językowej, reklamy, antyimigranckich żartów, muzyki rap w języku suahili, kreskówek indyjskich, a także recepcji telewizji chińskiej przez osobę straszą, nieznająca języka.

Wreszcie, $\mathrm{w}$ T\&T o wiele więcej uwagi poświęcono kwestiom gatunku i/lub produkcji danego typu medium (artykuły o editorials, live broadcasts, subtitles); tworzeniu tożsamości autorów/uczestników $\mathrm{w}$ programach telewizyjnych i artykułach gazetowych (profesjonalna, ekspercka, authority) i tożsamości widowni. $\mathrm{W}$ tym czasopiśmie spotkałyśmy się także z artykułami, których zaklasyfikowanie do jednej kategorii ze względu na przedmiot analizy było trudne. 
Jeśli porównamy problematykę artykułów, najbardziej kontrastowo będą prezentowały się D\&S i T\&T, stanowiąc rodzaj kontinuum rozciągającego się pomiędzy zainteresowaniem dyskursem medialnym jako narzędziem reprezentacji i kształtowania wizerunków grup oraz praktyk społecznych a dyskursem medialnym jako wynikiem praktyk ekonomicznych, społecznych, kulturowych i oddziaływania technologii, a jednocześnie praktyki dziennikarskiej jako kształtowanej przez język.

\section{Komunikacja internetowa}

Byłyśmy zdziwione stosunkowo małą obecnością analiz komunikacji internetowej. Materiały internetowe wydawały się nam dość łatwo dostępne; wiele się obecnie mówi o potędze tego kanału komunikacyjnego i jego istotności społecznej. $\mathrm{W}$ badanych czasopismach dyskursywnych okazał się jednak ledwo obecny jako przedmiot analiz.

Tabela 8. Dyskurs internetowy w badanych czasopismach.

\begin{tabular}{|l|c|c|c|c|c|c|}
\hline & LiS & DS & D\&S & L\&C & T\&T & Suma \\
\hline Internet & 3 & 13 & 8 & 8 & 7 & 39 \\
\hline
\end{tabular}

Źródło: opracowanie własne

We wszystkich czasopismach autorzy analizowali różne typy danych. W DS były to maile (w tym także spamy), chaty (randkowe, profesjonalne, edukacyjne), grupy wsparcia osób z różnymi problemami, blogi. W LiS: chaty, gry komputerowe, forum internetowe. W L\&C: chaty $w$ językach Indonezji, strony imigrantów, dyskusje na temat standaryzacji języka, użycie języka migowego pisanego. W D\&S i T\&T: portale społecznościowe (np. Facebook), komunikatory, fora, blogi, strony czasopism i TV, e-maile, reklama on-line. Dwa ostatnie czasopisma nie różniły się znacząco między sobą, nieco bardziej „problemowość społeczno-polityczna" (rasizm, gender, migracja, niepodległość) dała się zauważyć w D\&S, który jest bardziej nastawiony na KAD. Z metodologicznego punktu widzenia interesujący wydał nam się artykuł porównujący internetową stronę TV i TV jako taką.

\section{Podejścia teoretyczne}

W pięciu badanych czasopismach zarysowała się znacząca przewaga podejść teoretycznych, które w centrum swoich modeli konceptualnych umieszczają interakcję. Najwięcej jest bezpośrednich odwołań do analizy konwersacyjnej (21\% wszystkich artykułów) jako prawomocnej ramy teoretycznej (por. Rancew-Sikora 2007; Rapley 2010). Najwięcej odwołań do AK zarejestrowałyśmy w DS. Jest to także czasopismo, w którym udział materiału mówionego jest ponad siedmiokrotnie wyższy niż pisanego. Ważne miejsce $\mathrm{w}$ badanym materiale zajmuje także etnografia mówienia (lub antropologia komunikowania) (10\%), to podejście jest najbardziej charakterystyczne dla czasopism L\&C i T\&T. Najczęściej przywoływanym autorem jest Erving Goffman (14), którego prace były inspirujące zarówno dla przedstawicieli AK, jak i etnografii mówienia. Dwie kluczowe postacie $\mathrm{w}$ ramach etnografii mówienia - Dell Hymes i John J. Gumperz - są także wśród najczęściej przywoływanych autorów (odpowiednio 11 i 10 odwołań). Gumperz jest ważną postacią również w socjolingwistyce interakcyjnej, dziedzinie na pograniczu socjolingwistyki i etnografii mówienia, która notabene nie jest wyróżniana na poziomie streszczeń jako subdyscyplina, a odwołania do kategorii z tej dziedziny dokonuje się wymiennie pod szyldem albo etnografii (mówienia), albo analizy konwersacyjnej. Natomiast bezpośrednie odwołania do socjolingwistyki jako takiej pojawiają się najczęściej w L\&C i LiS (większość to odwołania do interakcyjnej odmiany socjolingwistyki); w sumie do socjolingwistyki odsyła 5\% streszczeń ze wszystkich czasopism. W streszczeniach pojawiają się także odwołania do interakcjonizmu symbolicznego (1\%) i etnometodologii (1\%). Na marginesie należy zauważyć, że obok Goffmana, Harold Garfinkel był uznawany za jednego z dwóch najważniejszych myślicieli, których prace ukształtowany ramy teoretyczne etnografii mówienia (Gumperz 2008: 216; por. Sarangi 2011: 375). Nieco dziwi fakt, że nazwisko Garfinkla nie pojawia się $\mathrm{w}$ abstraktach, kontrastuje to z zauważalnością nazwiska Goffmana. Także odwołania do pragmatyki (4\%), włączając $\mathrm{w}$ to jej ważny dział - teorię grzeczności, której autorzy, Brown i Levinson (1987), nawiązują bezpośrednio do koncepcji twarzy Goffmana - można uznać za oznakę zainteresowania interakcją. Pośrednio z intersubiektywnością dyskursu związany jest także nurt dialogiczny (1\%), inspirowany pracami Michaiła Bachtina (jego nazwisko jest drugie w „rankingu popularności” klasyków przywoływanych w streszczeniach - pojawia się 11 razy). W sumie dwie piąte artykułów w badanym materiale w mniej lub bardziej bezpośredni sposób odwołuje się do teorii interakcyjnych. W pozostałym materiale zauważalny jest udział artykułów, w których nie ma niedwuznacznych odsyłaczy teoretycznych, natomiast używane kategorie analizy wskazują na centralność interakcji.

Dla większości wyżej wymienionych nurtów teoretycznych istotne jest przezwyciężenie koncepcji języka zakładającej, że jest on po prostu odbiciem, istniejących niejako autonomicznie od procesu interakcji, myśli i wartości lub też ram komuni- kowania określanych przez relacje władzy i podporządkowania. Takie rozłożenie akcentów teoretycznych wydaje się mieć szczególnie istotne konsekwencje dla licznych analiz interakcji w kontekście instytucjonalnym. $W$ różnych podejściach interakcyjnych przeniesienie uwagi na sam proces interakcji skutkuje między innymi sformułowaniem tezy o odrębności reguł interakcyjnych od reguł na przykład reprezentacji zastanych lub procesów fizycznych; autonomiczności interakcji. Także kontekst $\mathrm{w}$ tych ujęciach jest postrzegany jako bardziej „miękki”, to jest współtworzony przez proces interakcji (Pawliszak, Rancew-Sikora 2012: 10). Rodowód "interakcyjny” powoduje, że nie język zastany - język jako system - jest w centrum zainteresowania analityków dyskursu, lecz procesualność mowy oraz to, jak porządek społeczny jest wytwarzany poprzez procesy komunikacyjne (zob. Grzymała-Kazłowska 2004: 28-29).

Jeśli na poziomie teoretycznym jest to przekonująca opcja, to z gruntu empirycznie zorientowana analiza dyskursu ma z koncentracją na procesualności pewne kłopoty. Na niektóre z tych problemów wskazywał Marek Czyżewski w artykule Elementy i całości (2008), zwracając uwagę między innymi na trudność przechodzenia od rejestracji i analizy lokalnych interakcji do uogólnień i wniosków obowiązujących poza lokalnym kontekstem, a z drugiej strony na pułapki uogólnień, które nie są zakorzenione w obserwacji rzeczywistych praktyk i doświadczeniu aktorów społecznych. Nieco inaczej ten dylemat ujmuje Michael Stubbs, nazywając go „paradoksem de Saussure'a” (2008: 315 [tłum. własne]). Stubbs zwraca uwagę na problem „nieobserwowalności” zarówno zjawisk strukturalnych (systemu językowego, który jest abstrakcją), jak i wydarzeniowych (mowy, rozgrywania 
się interakcji [performance], której wydarzenia są jednostkowe, fragmentaryczne, idiosynkratyczne). W przypadku tych drugich problematyczny jest nadmiar wydarzeń, które należałoby zaobserwować, by wyciągnąć wnioski dające się uogólnić, a więc takie, które wychodziłyby poza ramy wiedzy potocznej.

Analizowany materiał empiryczny nie dostarcza wyczerpujących informacji na temat tego, jak sygnalizowane dylematy podejść skupionych na interakcji są rozwiązywane. Pozwala natomiast na pewnego rodzaju wgląd $w$ to, jak $w$ streszczeniach kształtuje się relacja między zastosowanym podejściem a wnioskami z analizy. Po pierwsze, interakcja najczęściej jest traktowana jako środowisko, w którym powstają lub są dookreślane relacje, procesy i tożsamości społeczne. Przykładowo, lokalne zarządzanie mową jest widziane jako droga do nabywania wiedzy i kompetencji (przypadek diachronicznych badań mowy w miejscu pracy, opisujący nabywanie przez początkującą farmaceutkę profesjonalnych umiejętności w rozmowach z klientami apteki). Interakcja jest też środowiskiem, w którym ujawnia się płynność formalnych reguł, to jest formalne reguły zostają określone na nowo, zakwestionowane, renegocjowane $\mathrm{w}$ interakcji. Szczególnie ujawnia się to $\mathrm{w}$ analizach komunikacji instytucjonalnej: rama teoretyczna koncentrująca się na interakcji pozwala na ukazanie, jak reguły formalne są interpretowane i zmieniane poprzez interakcję. Przykładem może być streszczenie $z$ T\&T ukazujące silną obecność bezpośrednich zarzutów wobec siebie przez strony będące $\mathrm{w}$ konflikcie - mimo obecności mediatora, którego zadaniem (zgodnie z formalnymi regułami) jest zapobieganie bezpośredniej konfrontacji słownej.
Wreszcie - odwołując się do naszkicowanej wyżej dychotomii Czyżewskiego (2008) - streszczenia reprezentują głównie badania empiryczne „elementów", a jeśli odnoszą wyniki tych badań do poziomu "całości", to w sposób skrótowy - bez wyjaśnień (np. w przypadku streszczenia dotyczącego nabywania kompetencji profesjonalnych poprzez rozmowy z klientami apteki zaznaczono jedynie, że wyniki badań rzutują na rozumienie mechanizmów komunikowania w miejscu pracy; nie wyjaśniono natomiast, czy we wszystkich miejscach pracy, czy tylko na etapie wchodzenia do zawodu, jaki wpływ może mieć podział na pracę fizyczną i umysłową itd.).

Opozycyjne wobec podejść skupionych na interakcji są podejścia, których uwaga ogniskuje się na władzy i nierównościach. Obok analizy konwersacyjnej ten obszar uważany jest za tradycyjny dla socjologicznie zorientowanej analizy dyskursu (Grzymała-Kazłowska 2004; zob. także numer tematyczny "Studiów Socjologicznych" [2012, nr 1] pt. „Kontekst i władza w analizie dyskursu”, a szczególnie artykuł Pawliszaka i Rancew-Sikory [2012]). Na ten nurt w ramach analizy dyskursu duży wpływ miały prace Michela Foucaulta dotyczące praworządności, władzy-wiedzy i formacji dyskursywnych, kontrastujące $\mathrm{z}$ teorią działania komunikacyjnego Jürgena Habermasa (Czyżewski 2005: 515). Znaczenie dorobku Foucaulta dla analizy dyskursu było wielokrotnie sygnalizowane przez polskich autorów, natomiast $\mathrm{w}$ badanym materiale jego nazwisko pojawia się jeden raz. Jednocześnie drugim najczęściej przywoływanym w streszczeniach podejściem teoretycznym

${ }^{5}$ Tu jednocześnie warto podkreślić, że wybór fragmentów prac i koncepcji „,ojców założycieli" na potrzeby rozwoju danej dziedziny jest procesem selektywnym, który nie pozwal na wchłonięcie całej złożoności i zróżnicowania tych prac (np. Stachowiak 2012) jest krytyczna analiza dyskursu, której rdzeń stanowią badania dominacji oraz dążenia do obnażenia niesprawiedliwości społecznej $\mathrm{i}-\mathrm{w}$ miarę możliwości - jej naprawienia. Sądzimy, że KAD jest szkołą na tyle sformalizowaną i odrębną, że ma już „własnych klasyków” (m.in. van Dijka, Fairclougha, Wodak) i to ich właśnie nazwiska (a nie Foucaulta, Bourdieu, Habermasa czy Gramsciego) sygnalizują ramę teoretyczną KAD-u w streszczeniach. Jednocześnie na tworzenie się KAD-u miały wpływ także prace zachodniego marksizmu i krytycznych studiów kulturowych, a więc wielu przedstawicieli KAD-u nie wywodzi swojego ujęcia władzy i dyskursu (bezpośrednio) od Foucaulta.

Wydaje się, że w ramach analizy dyskursu to podejście KAD-u jest polskim socjologom znane najlepiej (np. Jabłońska 2006; Nijakowski 2006; por. Duszak i Fairclough 2008; zob. także większość tekstów w tym numerze). Przy tym niebezzasadnie uważa się, że KAD nie stanowi spójnej propozycji teoretyczno-metodologicznej (np. Trutkowski 2004: 48). Dlatego dla celów tego artykułu wspomnieć należy tylko, że pomimo eklektyzmu (por. artykuł Barbary Jabłońskiej w tym numerze), jednym z założeń ontologicznych KAD-u jest traktowanie języka jako powłoki zjawisk społecznych. Będąc ważną częścią rzeczywistości społecznej, język i komunikowanie wprzęgnięte są w procesy reprodukcji nierówności. I chociaż nierzadko język $\mathrm{w}$ reprodukcji nierówności ma rolę czynną, to same nierówności mają także inną rzeczywistość niż tylko językową, a język służy do ich naturalizacji. Zadaniem badacza jest wydobywanie na światło dzienne ukrytych w języku pułapek, których uczestnicy komunikacji nie są świadomi. Z jednej strony przypomina to proce- durę etnometodologiczną, gdzie badaczy interesowały metody zespołowego/wspólnego budowania porozumienia/wiedzy. Jednak KAD wyróżnia stosowanie „hermeneutyki podejrzliwości”, to jest brak założenia, iż praca jest zespołowa, że ludzie chcą porozumienia. Co więcej, intencjonalność aktorów może być w ramach KAD-u zwodniczą iluzją (np. w świetle koncepcji podmiotowości Foucaulta).

W badanym materiale do ramy teoretycznej KAD-u najczęściej odwoływano się w D\&S, najmniej - w LiS, L\&C i T\&T. Przykładami traktowania języka jako powłoki relacji nierówności, dominacji i wykluczenia jest między innymi analiza języka Brytyjskiej Partii Nacjonalistycznej, w której autorzy wysnuwają wniosek, że chociaż używane przez polityków kategoryzacje (membership categories) zakładają szerokie włączanie wszystkich grup obywateli, to de facto kategoria ta jest naznaczona rasowo i wyklucza kolorowych Brytyjczyków. Innymi słowy, powierzchnia sugerowałaby jeden typ relacji, ale KAD wydobywa spod powierzchni relacje prawdziwe (realizowane jest założenie o istnieniu innych wymiarów rzeczywistości oprócz interakcyjnej/komunikacyjnej). Używane formy dyskursywne konstruują wykluczenie, ale jednocześnie przyczyny wykluczenia wykraczają poza sferę komunikowania.

Warte odnotowania jest także to, że w D\&S czasopiśmie najczęściej korzystającym z KAD-u - drugą ważną ramą teoretyczno-metodologiczną była analiza korpusowa. Podstawowym założeniem teoretycznym analizy korpusowej jest traktowanie języka jako reprezentacji i odzwierciedlenia społeczeństwa i kultury (możliwe jest tu nakreślenie paraleli z hipotezą Sapira-Whorfa). Ważnym problemem jest reprezentatywność 
korpusu. Korpus, którego autorzy sądzą, że w odpowiednich proporcjach dobrali teksty reprezentujące najważniejsze odmiany języka w użyciu, nazywany jest korpusem zrównoważonym (choć zawsze podkreśla się, że język mówiony jest niedoreprezentowany we wszystkich korpusach językowych). Używanie analizy korpusowej ma - w zamyśle jej propagatorów - zaradzić „paradoksowi de Saussure'a" (Stubbs 2008) czy też dać badaczom możliwość, za pomocą technik komputerowych, połączenia „elementów" i „całości” (Czyżewski 2008), dostarczyć narzędzi do wnioskowania o "całościach", nie abstrahując zanadto od konkretnych użyć języka. Innymi słowy, „nieobserwowalność" przezwyciężana jest przez „reprezentatywność”: te „elementy”, które są typowe dla „całości”, mogą stanowić obserwowalne źródło wiedzy o nich.

W badanych artykułach stosunkowo rzadkie jest stosowanie dużych korpusów danych, szczególnie korpusów narodowych (zob. Przepiórkowski i in. 2012, w Polsce analiza korpusowa jest stosowana niemal wyłącznie przez lingwistów). Częściej od korpusów całego języka korzysta się z korpusów "celowych" - związanych z tematem badań lub typem komunikacji (np. korpus chińskich tekstów reprezentujących różne gatunki prawnicze z kilku lat). Poniekąd założeniem podejścia - szczególnie do korpusów językowych - jest istnienie normy językowej, określanej na podstawie częstotliwości rzeczywistych użyć wybranych form słownych, typów czy kolokacji wyrazów (tj. uzusu językowego). Właśnie w przypadku użycia korpusów językowych pojawiają się $\mathrm{w}$ badanym materiale propozycje, które sugerują, że jakościowa analiza powinna być uzupełniana analizą korpusową, szczególnie analizą kolokacji. Uzasadnieniem jest to, że w niej relacje ujawniają się w bardziej wymierny i dlatego godny zaufania (reliable) sposób. Choć niezbyt częste, takie propozycje maja daleko idące konsekwencje dla wyborów metodologicznych. Zdradzają zmęczenie interpretacja i potrzebę pewnego rodzaju "twardych faktów" (liczb, zależności statystycznych). Ta tendencja może być pochodną uprawiania analizy dyskursu jako podejścia mocno ukierunkowanego na praktykę społeczną, ściślej - na stosowanie jej do rozwiązywania problemów społecznych, o czym wspominałyśmy przy okazji komentowania zdecydowanej przewagi dyskursu instytucjonalnego w badanym materiale. $Z$ aplikacyjnością wiąże się potrzeba tworzenia - i sprzedawania - wiedzy eksperckiej, która najczęściej kojarzy się laikom ze zdolnością dostarczenia "twardych faktów" o całościach, nie zaś interpretacją znaczenia wybranych „elementów”.

W czasopiśmie D\&S obecna jest także psychologiczna analiza dyskursywna (por. Kurcz, Okuniewska 2011), w innych czasopismach reprezentowana znacznie słabiej. Częściowo może to być skutek preferencji redaktora naczelnego Teuna A. van Dijka, który jest jednym z wiodących przedstawicieli tego nurtu. Jednak personalia nie wyjaśniają wszystkiego. Psychologiczna analiza dyskursywna może być częściej wybierana w D\&S z powodu zainteresowania autorów tematami budowania tożsamości, odgrywania ról społecznych i stosowania kategoryzacji (group membership categories). Zaznaczyć też należy, że na podstawie analizy streszczeń można odnieść wrażenie, iż brakuje wyjaśnień, dlaczego autorzy decydują się na korzystanie $z$ tej perspektywy, o jakich wyborach teoretycznych - oprócz psychologicznej wizji aktora społecznego jako podmiotu obdarzonego emocjami i poznającego poprzez modele mentalne - ona świadczy.

Analiza narracyjna jest stosunkowo istotnym podejściem w badanym materiale, choć nie dominującym (odsyłacze do niej zawiera 5\% streszczeń). Jest to podejście autonomiczne $\mathrm{i}$ wewnętrznie heterogeniczne. $\mathrm{Z}$ jednej strony odwołuje się do analiz formalnych (np. sekwencji lub części składowych narracji), z drugiej zaś - do hermeneutyki Paula Ricoeura. Ciekawą obserwacją wydaje się to, że $\mathrm{w}$ badanym materiale analiza narracyjna jest interpretowana $\mathrm{w}$ duchu interakcjonistycznym w czasopiśmie, w którym przewagę ma AK (LiS). Przykładowo, narracja jest sposobem dookreślenia ról i produkowania wiedzy przez narratora i słuchacza. Natomiast $w$ streszczeniach $z$ L\&C, w którym zauważyłyśmy istotność odwołań do semantyki, także analiza narracyjna częściej występuje w wersji „,semantycznej”, to jest takiej, która ukazuje, jakie znaczenia są budowane poprzez narrację oraz jak narracja służy egzegezie sensu. Wychodząc poza ramę materiału naszych analiz, należy stwierdzić, że współczesne studia nad narracją szeroko korzystają z wielu lingwistycznych, literaturoznawczych i psychologicznych podejść i ram teoretycznych (np. Narrative Inquiry 2006; por. Trzebiński 2002).

Oprócz podjeść, które umieściłyśmy na krańcach „interakcja” versus „nierówności i władza”, $\mathrm{w}$ analizowanych tekstach pojawiają się także bardziej specjalistyczne ramy teoretyczne, takie jak na przykład dialektologia (tylko w LiS) lub lingwistyka ewolucyjna (tylko w L\&C). Węższe ramy teoretyczne wydają się być powiązane $\mathrm{z}$ ramami bardziej definicyjnymi dla danego czasopisma, to jest z dialektologią powiązana może być socjolingwistyka $-\mathrm{w}$ obu podejściach istotne jest zróżnicowanie i odmiany języka (w LiS). Lingwistyka ewolucyjna natomiast może być połączona $\mathrm{z}$ antropologizującymi podejściami w L\&C. Cechą dość typową całego materiału badawczego jest ponadto łączenie kilku podejść teoretycznych, na przykład analizy narracyjnej z konwersacyjną lub psychologicznej analizy dyskursywnej z KAD-em i AK. Na podstawie streszczeń najczęściej trudno uzyskać odpowiedź na pytanie, do jakich założeń teoretycznych przychylają się autorzy tych ujęć hybrydalnych. Czy łączenie podejść tworzy „nową jakość" teorii, czy też po prostu oznacza to, przykładowo, że przedmiotem artykułu jest konstruowanie tożsamości (psychologiczne podejście) w trakcie interakcji mówionej (AK), analizowane $\mathrm{w}$ perspektywie krytycznej (KAD). Najczęściej odnosiłyśmy wrażenie, że ten ostatni wariant lepiej odzwierciedla intencje autorów. Jako oznakę łączenia podejść interpretujemy także używanie odniesień do „,analizy dyskursu” bez przymiotników (5\%). Szeroko pojęta analiza dyskursu podawana była jako teoretyczny punkt odniesienia zarówno $\mathrm{w}$ tekstach traktujących o intertekstualności, jak i o praktykach włączania/wyłączania.

Generalnie analiza dyskursu reprezentowana przez badane czasopisma wydaje się stronić od wielkich teorii społecznych, bardziej interesuje się teoriami średniego zasięgu lub teorią i metodologią lingwistyczną.

Na końcu prezentujemy - $\mathrm{w}$ formie tabeli - rozkład odwołań do poszczególnych podejść teoretycznych w celu zasygnalizowania obecności także tych podejść, które w powyższej narracji zostały pominięte. 
Tabela 9. Dystrybucja podejść teoretycznych w badanych czasopismach.

\begin{tabular}{|c|c|c|c|c|c|c|c|}
\hline Podejścia & $\begin{array}{l}\text { LiS } \\
\text { (89) }\end{array}$ & $\begin{array}{c}\text { DS } \\
(155) \\
\end{array}$ & $\begin{array}{l}\text { D\&S } \\
(107)\end{array}$ & $\begin{array}{l}\text { L\&C } \\
\text { (122) }\end{array}$ & $\begin{array}{l}T \& T \\
(105) \\
\end{array}$ & SUMA & $\%$ \\
\hline AK & 13 & 73 & 16 & 9 & 18 & 129 & $21 \%$ \\
\hline KAD & 1 & 12 & 45 & 4 & 5 & 67 & $11 \%$ \\
\hline $\begin{array}{c}\text { Etnografia lub antropologia } \\
\text { komunikowania }\end{array}$ & 11 & 3 & 2 & 24 & 19 & 59 & $10 \%$ \\
\hline Socjolingwistyka & 27 & 4 & 6 & 20 & 1 & 58 & $9 \%$ \\
\hline Analiza narracyjna & 11 & 4 & 3 & 8 & 8 & 34 & $5 \%$ \\
\hline Psychologia dyskursywna & 0 & 5 & 17 & 5 & 5 & 32 & $5 \%$ \\
\hline DA & 2 & 11 & 11 & 2 & 4 & 30 & $5 \%$ \\
\hline Lingwistyka korpusowa & 1 & 5 & 12 & 3 & 4 & 25 & $4 \%$ \\
\hline Pragmatyka & 1 & 3 & 3 & 5 & 11 & 23 & $4 \%$ \\
\hline Semiotyka & 1 & 4 & 1 & 9 & 3 & 18 & $3 \%$ \\
\hline SFL & 0 & 2 & 4 & 0 & 9 & 15 & $2 \%$ \\
\hline Retoryka & 2 & 6 & 1 & 1 & 5 & 15 & $2 \%$ \\
\hline Interakcjonizm symboliczny & 4 & 4 & 0 & 0 & 0 & 8 & $1 \%$ \\
\hline Dialogizm & 0 & 0 & 1 & 1 & 5 & 7 & $1 \%$ \\
\hline Etnometodologia & & 0 & 1 & 0 & 5 & 6 & $1 \%$ \\
\hline Dialektologia & 6 & 0 & 0 & 0 & 0 & 6 & $1 \%$ \\
\hline Teoria języka & 0 & 0 & 0 & 6 & 0 & 6 & $1 \%$ \\
\hline Lingwistyka ewolucyjna & 0 & 0 & 0 & 5 & 0 & 5 & $1 \%$ \\
\hline
\end{tabular}

Źródło: opracowanie własne

170 @2013 PSJ Tom IX Numer 1
Kategorie analizy

Część dotycząca kategorii analizy będzie najbardziej obszerna, stwierdziłyśmy jednak, że poświęcenie temu tematowi szczegółowej uwagi będzie pożytecznym ćwiczeniem z "archiwizacji” i uporządkowywania "narzędzi badawczych" AD. Pogrupowanie kategorii sprawiło nam wiele trudności. Kategorie te niekiedy były explicite zdefiniowane w abstraktach, niekiedy zaś można było o nich wnioskować jedynie z opisu badań. Co więcej, niektóre z nich były kategoriami cen-

Tabela 10. Najważniejsze grupy kategorii analizy w badanych czasopismach.

\begin{tabular}{|c|c|c|c|c|c|c|}
\hline Kategorie analizy & LiS & DS & D\&S & L\&C & T\&T & Suma \\
\hline fonetyka & 6 & 2 & 2 & 2 & 2 & $\mathbf{1 4}$ \\
\hline składnia & 11 & 5 & 2 & 2 & 8 & $\mathbf{2 8}$ \\
\hline części mowy i leksyka & 7 & 13 & 14 & 6 & 8 & $\mathbf{4 8}$ \\
\hline semantyka & 22 & 30 & 24 & 33 & 14 & $\mathbf{1 2 3}$ \\
\hline rejestr i styl & 17 & 5 & 1 & 16 & 5 & $\mathbf{3 9}$ \\
\hline $\begin{array}{c}\text { tekst (markery dyskursywne, kohezja, } \\
\text { koherencja, cytowania, intertekstualnoś) }\end{array}$ & 5 & 19 & 6 & 8 & 14 & $\mathbf{5 2}$ \\
\hline gatunek & 4 & 14 & 9 & 4 & 8 & $\mathbf{3 9}$ \\
\hline narracja & 10 & 8 & 12 & 8 & 14 & $\mathbf{5 2}$ \\
\hline struktura rozmów codziennych & 6 & 39 & 3 & 5 & 8 & $\mathbf{6 1}$ \\
\hline akty mowy i inne kategorie pragmatyczne & 19 & 69 & 26 & 9 & 18 & $\mathbf{1 4 1}$ \\
\hline retoryka & 4 & 15 & 16 & 5 & 15 & $\mathbf{5 5}$ \\
\hline $\begin{array}{c}\text { strategie dyskursywne } \\
\text { kategorie socjologiczne }\end{array}$ & 64 & 52 & 44 & 43 & 49 & $\mathbf{2 5 2}$ \\
\hline
\end{tabular}

Źródło: opracowanie własne tralnymi, występującymi także $\mathrm{w}$ słowach-kluczach, inne zaś się tam nie pojawiały, ale opis badań wskazywał, że są ważne. Warto także podkreślić, że pojawiające się w abstraktach kategorie często nie występowały pojedynczo, ale łączone były z innymi kategoriami analizy. Poza tym, kategorie te są rożnie definiowane $\mathrm{w}$ zależności od perspektywy teoretycznej, a same perspektywy trudno było, ze względu na eklektyzm podejść, wyraźnie rozdzielić. Dlatego też zdajemy sobie sprawę $\mathrm{z}$ arbitralności zastosowanego przez nas podziału. 


\section{Fonetyka i składnia}

W artykułach bardzo rzadko podejmowano zagadnienia związane z fonetyką (intonacją, wymową, tonem głosu czy prozodią). Kategorie te pojawiły się jedynie w 14 artykułach, najczęściej w LiS. Nie oznacza to jednak, że socjofonetyka, którą najczęściej łączy się z pracami Williama Labova (1966) i Petera Trudgilla (1986), nie jest uprawiana. Raczej wynika to z daleko posuniętej specjalizacji czasopism, gdyż tego typu badania publikowane są na przykład w czasopiśmie „Language Variation and Change". Inną mało eksplorowaną kategorią była składnia (w sumie 28 artykułów). Być może rozważania na temat strukturalnych właściwości języka w słabym stopniu uwzględniają społeczne wymiary użycia języka i dlatego też badanie składni nie jest centralnym przedmiotem zainteresowań badaczy analizy dyskursu i stanowi jedynie narzędzie pomocnicze $\mathrm{w}$ analizach tekstu.

\section{Części mowy i leksyka}

Znacznie większe zainteresowanie wzbudzała leksyka i części mowy (48 artykułów), szczególnie w D\&S i DS. W D\&S najczęściej badane były kolokacje i konkordancja, a także przyimki, natomiast w DS analizowano cząstki ${ }^{6}$ (particles) pojawiające się $w$ konwersacjach $w$ językach indoeuropejskich, a także zaimki, analizowane w kontekście władzy, dystansu, prestiżu czy kategoryzacji. Prawdopodobnie ma to związek z kontynuowaniem etnograficznych i socjolingwistycznych prac Rogera Browna i Alberta Gilmana (1960) nad zaimkami oraz społecznymi relacjami władzy i prestiżu. Nie są natomiast analizowane rzeczowniki oraz związki

$\overline{6}$ Tłumaczymy ang. particles jako ",cząstki”, ponieważ w tekstach nie chodzi jedynie o partykuły, ale o szerszy zbiór czą-
stek w różnych jezykach, np. w j. ang. przysłówki, przedimki nieokreślone itd. rzeczownikowe, które zdaniem niektórych analityków dyskursu (np. Cutting 2011) stanowią podstawowe przedmioty analizy. Generalnie można było zauważyć, że zainteresowanie leksyką było ściśle powiązane z analizą innych, szerszych kategorii, takich jak warianty językowe czy gatunki (genre). Sama leksyka natomiast rzadko była przedmiotem analiz.

\section{Semantyka}

Semantyczny wymiar języka (128 artykułów) sprowadzał się do badania znaczeń, które w klasycznej typologii Charlesa Ogdena i Ivora Richardsa (1923) odpowiadały znaczeniom emotywnym: interpersonalnym i ekspresyjnym, zależnym od kontekstu. Potwierdza to tezę Neala R. Norricka (2008), że nastąił $\mathrm{w}$ analizach semantycznych zwrot od badań nad znaczeniami słów (semantyka leksykalna) do semantyki dyskursu, w której centralną rolę odgrywają polisemiczne zasoby i strategie interpretacyjne, systemy i kontekst znaczeń. Znaczenia wyłaniają się w procesach semiozy, są zarówno zasobem kulturowym, jak i produktem zaangażowanych w interakcje uczestników (Wetherell 2008). Dlatego też analizy semantyczne bliskie są pragmatycznej analizie języka, a granica między pragmatyką i semantyką zaciera się zgodnie z ujęciem znaczenia zaproponowanym przez Ludwiga Wittgensteina (Malmkjær 2002). Szczególnie widoczne jest to w krytycznej analizie dyskursu (Widdowson 1995). Semantyczne relacje związane są z badaniami szerszych wiązek tematycznych i makrotematów czy sieci semantycznych (Fairclough 2003; Wodak 2011a). W analizowanych czasopismach (przede wszystkim w T\&T) była to kategoria tematu „podstawowej jednostki semantycznej tekstu podsumowującej znaczenie lub główny przekaz danego tekstu lub jego części" (Wodak, Krzyżanowski
2011: 320). Inne podejście do semantyki pojawiło się w DS. Autorów tam publikujących interesowały przede wszystkim procesy tworzenia i interpretacji znaczeń $w$ codziennych interakcjach. Zgodnie z metodologią analizy konwersacyjnej badano, jak tematy rozmowy są wprowadzane, zmieniane i ustalane oraz czy istnieje koherencja między pojawiającymi się tematami. Badano także znaczenie określonych cząstek dyskursywnych (discourse particles) w różnych kontekstach społecznych, na przykład w zabawach dziecięcych. Natomiast w LiS i L\&C znaczenia analizowane były w kontekście społecznych i kulturowych repertuarów interpretacyjnych. Badano, jakie znaczenia nadawane są wypowiedziom czy tekstom skonstruowanym w określonym dialekcie/wariancie językowym, ale także jak wybór określonych środków językowych zmienia znaczenie wypowiedzi. $\mathrm{W}$ ramach tych badań wielokrotnie pojawiał się problem powiązania znaczeń pojawiających się $\mathrm{w}$ języku mówionym i pisanym z tożsamością społeczną (np. płcią) i tożsamością zbiorową. Znaczenia w tym ujęciu są zarówno ekspresją tożsamości, ale także jej stabilizatorem.

\section{Rejestr i styl}

Rejestr to „odmiana języka, z którą łączą się określone wybory leksykalne i składniowe oraz konwencje pragmatyczne" (Wodak, Krzyżanowski 2011: 318). Opisuje sposoby komunikowania się ludzi w określonych sytuacjach społecznych. W gramatyce funkcjonalno-strukturalnej rejestr jest konfiguracją znaczeń w językowych wariantach, opisywaną w kategoriach funkcji ideacyjnej, interpersonalnej i tekstowej, jaką członek danej kultury „wiąże typowo z określonym typem sytuacji” (Halliday 1978: 111 [tłum. własne]). Ponieważ analiza językowa prowadzona jest równolegle $\mathrm{z}$ ana- lizą sytuacyjną, rejestr jest kategorią analityczną szczególnie często wykorzystywaną w badaniach socjolingwistycznych i etnograficznych zainteresowanych analizą zróżnicowania językowego nie tylko w obrębie społeczeństwa, ale także jego segmentów (np. analizy Basila Bernsteina dotyczące zróżnicowania klasowego) czy określoną sytuacją mówienia. Rejestry bada się między innymi pod kątem zróżnicowania uczestników i ich ról społecznych, kontekstu sytuacyjnego, otoczenia, kanału komunikacji, celu i tematu. W badanych artykułach analizy rejestru pojawiły się 22 razy, niemal wyłącznie w LiS i L\&C. W perspektywie socjolingwistycznej analizowano $\mathrm{w}$ nich warianty językowe, takie jak: języki standardowe/niestandardowe, dialekty, a także procesy zmiany rejestrów w konwersacjach, powiązane ze strukturą uczestnictwa czy ewolucją rejestrów w związku z pojawieniem się grup dominujących (np. zmiana rytualnych przemówień $\mathrm{w}$ Indiach pod wpływem duńskich kolonistów). Ważną koncepcją w badaniu rejestrów była koncepcja urejestrowienia (enregisterment), czyli procesów „poprzez które językowe repertuary są różnicowane i społecznie rozpoznawane" (Agha 2003: 231 [tłum. własne]). W ramach tej koncepcji badano procesy dominowania języka w konwersacjach dwujęzycznych i ustalanie hierarchii językowych powiązanych z hierarchiami społecznymi, a także procesy standaryzacji języka i wyłaniania się nowych dyskursów (np. badania etnograficzne na temat wyodrębniania się dyskursu psychiatrycznego w Bangladeszu). Należy zauważyć, że bardzo rzadko analizowano rejestry standardowych języków europejskich (pojawiały się analizy dialektów), najczęściej zaś były to języki lub dialekty pozaeuropejskie, na przykład otomangueński (Meksyk), putonghua (Chiny). 
Stylistyka w tradycyjnym ujęciu była częścią retoryki, jednakże obecnie analiza stylów prowadzona jest także na gruncie innych perspektyw badawczych i pól analiz (np. stylistyka kognitywna, feministyczna, pragmatyczna), dlatego też na potrzeby tego artykułu zdecydowano się wyróżnić tę kategorię analityczną. Analiza stylistyczna dąży do opisu środków językowych, jakimi posługuje się jednostka, aby osiągnąć zamierzony cel komunikacyjny (por. Lisowska-Magdziarz 2006: 74). Jednakże jednostka podejmując wybory językowe (w zakresie leksyki, syntaktyki, gramatyki), nie tylko tworzy indywidualny styl komunikowania, ale jako autor wypowiedzi przynależy do grupy społecznej czy kręgu społecznego, a także kulturowego, który wywiera wpływ na styl wypowiedzi jednostek (Shuy 2008). W rezultacie tworzone są wypowiedzi o względnie spójnych cechach leksykalnych i strukturalnych, które mogą być analizowane z perspektywy jednostki (np. styl prezydenta), grupy, do której przynależy (np. polityków) czy czasu, w którym wypowiedź powstała (np. późna nowoczesność) (por. Carter, Malmkjær 2002). Socjolingwiści interesują się także zmianami stylów (style-swiching) w zależności od kontekstu komunikowania (podejście socjolingwistyczne). Etnograficznie zorientowane badania języka zajmują się relacją kultura-styl językowy. W badanych artykułach analiza stylistyczna pojawiła się 17 razy, niemal wyłącznie w LiS i L\&C, służyła do opisu wypowiedzi charakterystycznych dla określonej kategorii jednostek (np. młodzieży, raperów, polityków, sędziów) lub tekstów pojawiających się w konkretnych kontekstach społecznych i związana była $\mathrm{z}$ analizą gatunków (np. w powieści japońskiej, wiadomościach telewizyjnych, brazylijskim hip-hopie, modlitwach Afroamerykanów). W L\&C zwracano także uwagę na zjawisko zmia- ny stylów oraz w kilku przypadkach próbowano powiązać analizę stylistyczną z badaniami tożsamości (Żydzi w Ameryce) oraz podtrzymywaniem podziałów społecznych (reprezentacja wariantów językowych w telewizji greckiej), zatem eksplorowane było przede wszystkim podejście socjolingwistyczne i etnograficzne. Nie prowadzono także analiz stylu wypowiedzi wybranych osób publicznych czy społeczeństw w określonych warunkach historycznych.

\section{Tekst}

Lingwistyka tekstowa definiuje tekst jako jednostkę analizy szerszą niż zdanie, a główne zainteresowanie badaczy skupia się na analizie organizacji tego tekstu, takich jego cechach, jak kohezja, koherencja, intencjonalność, intertekstualność (Carter, Malmkjær 2002). W badanych czasopismach tekst był przedmiotem analiz w 46 artykułach, jednakże gdy w DS zajmowano się przede wszystkim markerami dyskursywnymi nadającymi tekstowi wewnętrzną strukturę, a zatem interesowano się cechami wewnątrzkontekstowymi (Wodak 2011a), w T\&T i D\&S częściej pojawiały się analizy dotyczące intertekstualności (badanie relacji między tekstami) i interdyskursywności (analiza powiązań między dyskursami). Przykładem takich analiz mogą być badania sposobów rekontekstualizacji islamu po 11 września czy wykorzystywania transkrypcji wypowiedzi uchodźców w dokumentach urzędowych.

\section{Gatunek}

Gatunek charakteryzuje się względnie stałymi formami językowymi, strukturą, celami komunikacyjnymi, społecznym i instytucjonalnym kontekstem. Kategoria ta łączy ze sobą analizy tekstu (typ tekstu) oraz działania. W analizowanym materiale badawczym kategoria gatunku najczęściej pojawiała się w DS (14 artykułów). Przeważało podejście strukturalno-funkcjonalne, w którym bada się „strukturę gatunkową", czyli sposób, w jaki poszczególne elementy są ze sobą powiązane i ich sekwencje pojawiające się w konwersacjach w życiu codziennym, najczęściej w sytuacjach uwzorowanych i zrytualizowanych ze względu na typ uczestników i ich cele, a następnie tworzy się typologie. W kilku tekstach analizie poddano zjawisko hybrydyzacji gatunków. W T\&T także przeważało podeście strukturalno-funkcjonalne, jednak gatunek rzadziej był tam centralną jednostką analizy, towarzyszył analizie korpusowej, a także narracyjnej. W D\&S gatunek najczęściej powiązany był $\mathrm{z}$ analizą retoryczną, ale także analizą tekstu i intertekstualności oraz etnografii. $\mathrm{W}$ tekstach LiS i L\&C analiza gatunku pojawiała się sporadycznie, w kontekście badań socjolingwistycznych i antropologii języka. Były to na przykład analizy dwujęzycznych tekstów literackich, piosenek raperów z Algierii i Maroka, gatunków pojawiających się w językach Indian Północnoamerykańskich (nazywanie miejsc, rekontekstualizacja Biblii za pośrednictwem gatunków używanych przez plemię Nawaho). Charakteryzowano takie gatunki, jak: e-maile biznesowe, spotkania biznesowe, ogłoszenia o pracę, codzienne rozmowy telefoniczne, opowieści wplecione w konwersację czy teksty naukowe (raporty z badań, podręczniki akademickie, opisy czasopism, recenzje), a także gatunki prawnie regulowane. Potwierdza się tutaj teza, że pewne gatunki są szczególnie często przedmiotem analiz, na przykład gatunki polityczne (wywiady, przemówienia, dokumenty) (por. Fairclough 2006), gatunki akademickie (np. Myers 1990) i biznesowe (Bhatia 1993). Zwrócono także uwagę na nowe ga- tunki pojawiające się w przestrzeni Internetu, jednakże były to analizy rzadko prowadzone przez badaczy.

\section{Narracja}

Mimo iż zauważa się, że narracja jest najbardziej rozpowszechnią formą komunikowania (Ricoeur 1992; Hymes 1996), w analizowanych czasopismach nie była ona dominującą kategorią analityczną i często łączono ją z innymi kategoriami, takimi jak gatunek, metafora, czy tożsamość. Dla celów analitycznych można podzielić badania nad narracją na kilka nurtów. Pierwszy z nich to nurt klasycznego strukturalizmu, drugi nurt badań kognitywny - analizuje sposoby, w jakie ludzki umysł porządkuje zdarzenia $\mathrm{w}$ sekwencyjną ramę czy schemat $\mathrm{w}$ procesie konstruowania i interpretacji narracji (zob. Trzebiński 2002; Kurcz, Okuniewska 2011). Oba te nurty były nie reprezentowane $\mathrm{w}$ analizach, prawdopodobnie dlatego, że pomijany jest kontekst społeczny, a wyakcentowane struktury formalne lub kognitywne. Trzeci nurt badań prowadzonych $\mathrm{w}$ ramach socjolingwistyki ujmuje narracje jako opowieść o osobistych doświadczeniach jednostki. Tu także prowadzone są analizy strukturalne, w których odsłaniane są stabilne wzory rządzące organizacją sekwencyjną zdarzeń w strukturze powierzchniowej (Labov, Waletzky 1967), ich zróżnicowanie ze względu na klasę społeczną, płeć, wiek, region, przynależność etniczną opowiadającego. Ten nurt analiz pojawiał się w LiS i L\&C najczęściej w kontekście badań nad typami narracji i ich charakterystykami w językach pozaeuropejskich (np. Nawaho, dialektach australijskich). Do tego można także dodać poststrukturalistyczny nurt analizy władzy-wiedzy, która poprzez opowieści jest społecznie reglamentowana i regulowana oraz badanie nad pozycjonowaniem 
jednostki (Harré, van Langenhove 1999), a także poszukiwanie „wielkich narracji”, czyli kulturowo ukształtowanych schematów porządkujących wiedzę. Ten typ badań pojawił się w T\&T i D\&S, łączony był z podejściem dialogicznym lub etnograficznym. Narracja jest medium, poprzez które grupy eksperckie podtrzymują władzę, ale także medium negocjacji (np. wywiady policyjne, codzienne rozmowy) i konstruowania tożsamości (migrantów, dewiantów, japońskich starszych kobiet, znanych osobistości scenicznych). Niekiedy badano jedynie wybrane elementy językowe w narracji: użycie metafor, pojawianie się dwujęzyczności czy „wielkich narracji". Pojawiły się także artykuły, które trudno zaklasyfikować do wymienionych nurtów. Dotyczyły one narracji wizualnej i przestrzennej. Ciekawym zjawiskiem jest renesans Bachtinowskiej kategorii chronotopu, wykorzystywanej już niegdyś $\mathrm{w}$ badaniach antropologicznych (Basso 1979), która pojawiła się w 9 artykułach o narracji, głównie w L\&C.

\section{Struktura rozmów codziennych}

Badanie struktur rozmów codziennych to główny cel, jaki stawia sobie analiza konwersacyjna (zob. Rancew-Sikora 2007; Rapley 2010). W abstraktach pojawiało się kilka kategorii analitycznych charakterystycznych dla AK: kolejki, wypowiedzi przyległe, sekwencje, rozwijanie tematów. Analiza kolejek pokazuje, w jaki sposób uczestnicy konwersacji interpretują wypowiedzi rozmówców i dopasowują do tej interpretacji własną wypowiedź (Drew 2001), tworząc $w$ ten sposób przestrzeń intersubiektywną (Schegloff 1992). Dlatego też podstawową jednostką analizy są pary wypowiedzi przyległych, składające się z następujących po sobie kolejek. Jednakże nie jest tak, że pary te występują zawsze po sobie, ale możliwe jest opóźnione pojawienie się drugiej części pary, którą poprzedzają sekwencje wstawione (insertion sequence) (Schegloff 1972) lub sekwencje poboczne (side sequence), a także różne typy sekwencji poprzedzających, przygotowujących kolejkę lub ją kończących (por. Liddicoat 2007). Analiza struktury to także analiza poruszanych $w$ rozmowie tematów: rozpoczynanie nowego tematu, jego zmiany, wprowadzanie podtematów i ich kończenie oraz sposobów, w jaki interlokutorzy nawiązują konwersację i ją kończą. Analiza struktur rozmów codziennych dominowała w DS. Analizowane były przede wszystkim kolejki i większe sekwencje konwersacyjne w różnych kontekstach społecznych: terapeutycznych, instytucjonalnych (np. praca, sąd, szkoły wyższe) oraz konwersacjach codziennych. Analizowano takie zjawiska, jak na przykład wyrażanie niezgody/zgody, stawianie trudnych pytań, sytuacje komiczne, pojawianie się kolejek niedokończonych, budowanie rozbudowanych sekwencji lub długich kolejek, inicjowanie i przejmowanie kolejek $\mathrm{w}$ sytuacjach zebrań oficjalnych, budowanie sekwencji $\mathrm{w}$ konwersacjach wzajemnie obrażających się chłopców. Badano, a także porównywano, konwersacje prowadzone $\mathrm{w}$ różnych językach i dialektach, ale także konwersacje prowadzone przez szczególne kategorie osób: dzieci, osoby jąkające się, a także osoby chore na demencję. Natomiast bardzo rzadko badano sposoby inicjowania i zamykania tematów rozmów.

\section{Akty mowy i inne kategorie pragmatyczne}

Jak podkreślają analitycy dyskursu, bardzo trudno jest wytyczyć demarkacyjną linię oddzielającą analizę dyskursu od pragmatyki: „mówi się, że pragmatyka czasami zawiera $\mathrm{w}$ sobie analizę dyskursu - lub odwrotnie" (Brinton 2008 [tłum. własne]). W książkach poświęconych pragmatyce (np. Yule 1996) analiza konwersacyjna jest częścią makropragmatyki (por. Schneider 2005). Z drugiej strony kategorie pragmatyczne, takie jak wyrażenia deiktyczne czy presupozycje, stały się integralną częścią analizy dyskursu. Jeśli przyjąć, że w ramach pragmatyki realizowane są zróżnicowane badania nad językiem, to do pragmatyki można także włączyć analizy socjolingwistyczne (por. Levinson 2010). Zdając sobie sprawę z trudności, jakie związane są z preparowaniem klasyfikacji kategorii analitycznych, zdecydowałyśmy, na potrzeby tego artykułu, podzielić je na kategorie, które są najczęściej spotykanymi kategoriami analitycznymi w obszarze pragmatyki: wspomniane już wyrażenia deiktyczne i presupozycje oraz implikatury, grzeczność i akty mowy. W sumie kategorie te pojawiły się 141 razy, najwięcej było ich w DS, a najczęściej spotykaną kategorią były akty mowy, których wyróżnienie wymaga wyjaśnienia.

Teoria aktów mowy związana jest z pracami filozofów języka (m.in. John L. Austin, John Searle, Paul Grice) analizujących czynności illokucyjne i ich typy (np. Searle wyróżnił: asercje, akty dyrektywne, komisywne, ekspresywne, deklaratywne). Wadą tych badań z punktu widzenia analizy dyskursu jest skupienie się na intencjach mówiącego. Jeśli natomiast, idąc za sugestią Roma Harrégo, oddzielimy działanie od aktu, wtedy działanie (zgodnie z propozycją Alfreda Schütza) będzie intencjonalne, a akt „wspólnie konstruowanym społecznym znaczeniem działania" (Harré 2008: 696 [tłum. własne]). Akty mowy w takim rozumieniu mogą być obecne także w analizie konwersacyjnej. W badanych abstraktach tak rozumianych aktów mowy było 117, z czego 60 w DS. Korzystając z podziału aktów mowy zaproponowanego przez Searla, można stwierdzić, że najczęściej były to dyrektywy (62 abstrakty), takie jak na przykład skargi, prośby, propozycje, rady, zaproszenia; asercje (35 abstraktów), na przykład zgoda, niezgoda, osąd, opis. Akty ekspresyjne występowały znacznie rzadziej (19 abstraktów). Nie było natomiast w ogóle aktów komisywnych, to jest wypowiedzi, za pomocą których mówiący określa swoje zachowanie w przyszłości, być może dlatego, że niezbyt wyraźnie powiązane są z działaniami społecznymi. Inne wymienione kategorie pragmatyczne pojawiały się w badaniach znacznie rzadziej i najczęściej jako elementy teorii (np. teorii grzeczności: 7 artykułów) czy w towarzystwie innych kategorii (np. wyrażenia deiktyczne: 8 razy). Kategoria presupozycji czy implikatur nie występowała w abstraktach, jednakże nie oznacza to, że nie pojawiała się $\mathrm{w}$ artykułach jako element analiz dyskursu.

\section{Retoryka}

W analizie dyskursu retoryka to nie tyle sztuka pięknego przemawiania, ale strategiczne praktyki komunikacyjne stosowane $\mathrm{w}$ różnych obszarach życia publicznego (Ilie 2006). Analiza retoryczna to „badanie zastosowania i skutków wywołanych przez językowe (w tym niewerbalne) oraz inne semiotyczne środki perswazji $\mathrm{w}$ kategoriach retorycznych" (Reisigl 2011: 152). Efekt perswazyjny osiągany jest za pomocą racjonalnych schematów argumentacyjnych (logos), uprawomocnienia osoby mówiącej (ethos) lub wywoływania emocji (patos). Stosowane są zróżnicowane figury retoryczne oraz tropy (np. aluzje, animizacje, eufemizmy, metafory, parafrazy, powtórzenia, synekdochy, wyliczenia) oraz toposy. Nie pełnią one funkcji ornamentów, ale spełniają ważne metafunkcje ideacyjne: konstruują i kategoryzują rzeczywistość społeczną, tworzą jej uproszczone reprezentacje, selekcjonują obiekty i porządkują je, a także metafunkcje interpersonalne: wzmacniają tożsamość zbiorową 
i solidarność wewnątrzgrupową, wytwarzają poczucie ładu społecznego lub chaosu, legitymizują działania aktorów społecznych, a także mobilizują do działania (Reisigl 2006). Krótko mówiąc, „,kontrolują umysł" (van Dijk 2008: 357 [tłum. własne]). Omówione funkcje obecne były $\mathrm{w}$ analizowanych abstraktach, w których kategorie retoryczne pojawiły się 55 razy, najczęściej w DS (12 razy) i były niemal wyłącznie związane $\mathrm{z}$ analizą tekstów pisanych, zazwyczaj w kontekście KAD-u. To potwierdzałoby tezę, że współcześnie retoryka jest związana z pismem, przekazem skierowanym do „nieobecnej publiczności” za pośrednictwem mediów, która pozbawiona jest możliwości pełnego uczestnictwa w aktach mowy (por. Ong 1982; Hunter 1990). Najczęściej były to analizy tekstów naukowych (książek, abstraktów), ale także dyskursów politycznych. Kategorie retoryczne często powiązane były z funkcją legitymizująca, uprzywilejowującą pewien sposób przedstawiania świata, a także manipulującą opinią publiczną. Podobnie funkcjonowały one w T\&T i D\&S. Retoryka pojawiała się tam w kontekście dyskursu politycznego, ale także $\mathrm{w}$ powiązaniu $\mathrm{z}$ analizą perswazyjnych tekstów biznesowych (reklam) lub komunikacji instytucjonalnej (sądowej) oraz retorycznego ustalenia i podtrzymania dobrych relacji za pośrednictwem e-maili. W LiS i L\&C kategorie te pojawiały się bardzo rzadko i zwykle w kontekstach pozaeuropejskich (np. analiza zmiany politycznej retoryki $\mathrm{z}$ tradycyjnej na nowoczesną w zurbanizowanych przestrzeniach Madagaskaru, strategie retoryczne użyte $\mathrm{w}$ dyskusji nad rewitalizacją języka w społeczności Pueblo, Meksyk) i były one związane z metafunkcją ideacyjną (reprezentacje), a także interpersonalną (mobilizacja do działania, legitymizacja działań).
Na osobną uwagę zasługują metafory. Pełnią one szczególnie ważną funkcję w KAD-zie i w analizie narracji. Używane są analizach dyskursów wykluczania, kategoryzacji zbiorowości i grup społecznych (Wodak 2011b). W tym podejściu metafora nie jest kategorią stylistyczną, ale kognitywna. Jak sugerują prace Georga Lakoffa i Marka Johnsona (1988), metafory są sposobem konstruowania świata, jego kategoryzacji i konceptualizacji, ale także narzędziem perswazji, tym silniejszej, im bardziej metafora jest znaturalizowana (Fairclough 1992). Metafory mogą być analizowane nie tylko w kontekście ideacyjnym, ale także strukturalnym, jak jest to badane w lingwistyce funkcjonalno-strukturalnej, w której metafora jest tworzona poprzez strukturalne przemieszczenia grupy orzeczenia $\mathrm{w}$ obrębie zdania (Taverniers 2006). Metafory pojawiły się w sumie w badanych tekstach 20 razy, najczęściej w D\&S (10 razy). Analizowane były na przykład metaforyczne wyrażenia służące kategoryzacji, używane przez bośniackie kobiety, które były ofiarami gwałtów, badano także metafory służące do opisu procesu globalizacji, kraju jako miejsca zamieszkania (kraj to budynek), języka (język to przedmiot posiadania), biotechnologii (metafory strachu), SARS (SARS to wojna), choroby nowotworowej (nowotwór to wojna), a także metafory normalizujące wojnę w konflikcie izraelsko-libańskim. Analizowano także zmianę sposobów metaforyzacji przeciwników politycznych. Dominowało podejście kognitywistyczne, chociaż w dwóch przypadkach (w D\&S) badano metafory gramatyczne (np. porównując z kognitywnymi).

\section{Strategie dyskursywne}

Strategie dyskursywne to intencjonalnie podejmowane przez jednostki działania komunika- cyjne, w których za pomocą wybranych środków językowych jednostka pragnie osiągnąć określone cele praktyczne, polityczne, psychologiczne, komunikacyjne w najbardziej efektywny sposób. Środki te mogą mieć charakter semantyczny (co się mówi), jak i formalny (jak się mówi) (por. Cots 2006). Kategorie analityczne, które pojawiają się $\mathrm{w}$ badaniach strategii, są kategoriami pragmatycznymi i retorycznymi, jednakże ze względu na szczególną rolę, jaką pełną strategie w KAD-zie, wyodrębniono je jako osobną kategorię. Wśród strategii dyskursywnych wymienia się: redefiniowanie znaczeń, upraszczanie semantyczne, strategie pozytywnej prezentacji siebie i negatywnej prezentacji innych: nominalizacje, etykietyzacje, strategie argumentacyjne, wyrażanie zaangażowania, wzmacnianie lub osłabianie mocy illokucyjnej wypowiedzi (Blommaert 2005; Wodak 2011b). W analizowanych abstraktach strategie dyskursywne jako główna kategoria analizy pojawiły się 44 razy, w zdecydowanej większości w D\&S (33 razy). Najczęściej analizowane były strategie argumentacyjne (15 razy), nominalizacja i predykacja (12 razy), nieco rzadziej legitymizacja (6 razy). W przypadku strategii argumentacyjnych uwaga badaczy skupiła się na dyskursie politycznym. Przykładem takich analiz są: przemówienia Busha na temat wojny w Iraku, debata we Francji na temat przystąpienia Turcji do UE. Pojawiły się także badania strategii argumentacyjnych w narracjach czy rozmowach w kontekście instytucjonalnym lub codziennym (np. strategie argumentacyjne stosowane $\mathrm{w}$ narracjach o asymilacji czy strategie kontroli w hiszpańskim urzędzie imigracyjnym). Nominalizacje i predykacje pojawiły się w kontekście dyskursów politycznych wykluczeń, ale także negocjowania tożsamości społecznej i zbiorowej (np. tenisistek, policji wymuszającej łapówki czy tożsamości narodowej Chin). Strategie legitymizacji analizowano głównie w dyskursach eksperckich (ochrona środowiska) i politycznych (np. tworzenie pamięci społecznej Zagłady w ksiaż̇kach historycznych w Izraelu czy polityki społecznego wykluczenia bezdomnych).

\section{Kategorie socjologiczne}

Kategorie socjologiczne były kategoriami najczęściej występującymi, co nie jest zaskakujące, bowiem analizowane czasopisma badają język w kontekstach społecznych. W sumie kategorie te pojawiły się przede wszystkim w DS i LiS. W poniższym omówieniu uwzględniono jedynie te kategorie społeczne, które pojawiły sie najczęściej (minimum 20 razy). Najczęściej pojawiała się kategoria tożsamości (w sumie 64 razy). Dominuje ona w LiS i jest to ogólnie najczęściej występująca tam kategoria socjologiczna (26 razy), ale pojawia się ona także $\mathrm{w}$ pozostałych czasopismach. Tożsamość jest traktowana jako dynamiczny i zmieniający się konstrukt wytwarzany $\mathrm{w}$ procesie komunikowania, kategoryzacja własnej osoby $\mathrm{w}$ kontekście relacji z innymi grupami społecznymi, a nie jako względnie trwała właściwość przypisana jednostce (van Dijk 2009). Takie podejście dominowało w DS i D\&S. Analizowano sposoby konstruowania tożsamości $\mathrm{w}$ narracjach (np. żebraków w meczetach, dzieci autystycznych), rozmowach codziennych (np. rozmowach homoseksualistów), grupach dyskusyjnych (zebrania w pracy, dyskusje w klasie szkolnej) i często wiązano z takimi kategoriami, jak płeć czy rasa, a także dominacja i władza. W LiS i T\&T częściej analizowano powiązania zachodzące między tożsamością społeczną i zbiorową a dialektami, konfliktami językowymi czy polityką językową 
krajów europejskich (np. Irlandii, Hiszpanii), jak i pozaeuropejskich (np. Pakistan, Chiny, Brazylia, dialekty Indian północnoamerykańskich).

Druga pod względem częstości występowania była kategoryzacja (membership categorisation) (44 razy). Pojawiła się ona zarówno w T\&T, D\&S, jak i w DS. W D\&S kategoryzacja była strategia dyskursywną polegającą na typizacji aktorów społecznych, często związaną z podziałem na grupy obce (out-group) i wiązano ją z innymi strategiami dyskursywnymi, takimi jak predykacje czy legitymizacje. Badano na przykład sposoby kategoryzowania osób zażywających amfetaminę $\mathrm{w}$ dyskursie medycznym, kategorie etniczne stosowane w państwowych urzędach statystycznych czy rasistowskim dyskursie elit politycznych w Hiszpanii. W DS to pojęcie analityczne związane było $\mathrm{z}$ kategoriami pojawiającymi się $\mathrm{w}$ trakcie rozmowy $\mathrm{w}$ analizie konwersacyjnej, na przykład w wywiadach psychiatrycznych, zabawach dziecięcych czy wywiadach z osobami ocalałymi z Holocaustu. W T\&T pojawiały się oba typy tych podejść.

Trzecią co do częstości występowania kategorią był kontekst. Można przypuszczać, że większość artykułów w tych czasopismach implicite zakłada istnienie kontekstu społecznego, jednakże w 37 przypadkach kategoria ta została specjalnie wyróżniona w streszczeniu. Sposób ujęcia kontekstu różnił się w zależności od czasopisma: najbardziej wąskie ujęcie pojawiło się w DS (bezpośredni kontekst konwersacji), najszersze zaś w L\&C, gdzie kontekst stanowiły czynniki socjokultulturowe, często uzupełnione analizą historyczną.

Kolejną kategorią pojawiającą się $\mathrm{w}$ analizowanym materiale badawczym (26 razy) są sądy war- tościujące (evaluation, appraisal), które wyrażaja postawę nadawcy wobec przekazywanych treści. Często są one analizowane w kategoriach binarnych opozycji (np. dobry/zły) na poziomie leksyki, ale także szerszych struktur tekstu. Ich funkcją jest konstruowanie i podtrzymywanie istniejacego w danej społeczności ładu aksjonormatywnego, a także budowanie relacji między nadawca i odbiorca poprzez potwierdzanie podzielanych norm i wartości (Thompson, Hunston 2006). Ta kategoria pojawiła się przede wszystkim w T\&T (15 razy), w kontekście badań nad dyskursem akademickim, recenzjami filmów, a także dyskursem politycznym na temat etniczności, rasy i problemów związanych z migracjami.

Wspólnoty komunikacyjne (speech community) jako kategoria analityczna pojawiały się ze zbliżoną częstością (23 razy), jednakże głównie w L\&C, przede wszystkim $w$ badaniach nad grupami etnicznymi. Zauważalna była także obecność kategorii władzy, dominacji i ideologii, jednakże trudno jest podać dokładną częstotliwość ich występowania, bowiem są one nieodłączną częścią KAD-u dominującą w D\&S. W innych czasopismach kategorie te pojawiały się $\mathrm{w}$ kontekstach dominacji i władzy w konwersacjach (DS) oraz polityki językowej (L\&S i LiS).

\section{Metody}

Autorzy artykułów rzadko ujawniali w abstraktach zastosowane metody badawcze. Być może wynika to z przyjętych założeń teoretycznych, które wskazują odpowiednią dla nich metodologię badań. Metody stawały się przedmiotem zainteresowania $\mathrm{w}$ wybranych przypadkach: gdy stosowano wiele metod badawczych, gdy były to metody rzadko stosowane $\mathrm{w}$ danym podejściu teoretycznym lub artykuł dotyczył nietypowego przedmiotu badań (np. zdjęć). Najczęściej występujące metody to wywiad i badania etnograficzne (zwykle połączenie wywiadów i obserwacji [47 artykułów]). Wywiady najczęściej pojawiły się w DS w związku z analizami narracji i związanych z nią kategorii tożsamości oraz w LiS, i tu przeważały wywiady socjolingwistyczne na temat praktyk językowych obowiązujących w danej społeczności (np. na temat sposobów wymawiania -ing w języku angielskim, opinie na temat rewitalizacji szkockiej odmiany gaelic czy wywiady z nauczycielami języka angielskiego). W przypadku badań etnograficznych pojawiły się one głównie w LiS i L\&S w kontekstach badań społeczności językowych i komunikacji dzieci w klasie szkolnej. Prowadzono także rozważania metodologiczne na temat transkrypcji (8 artykułów w T\&T i DS), dotyczące autorytetu badacza $\mathrm{w}$ interpretowaniu nagrań dźwiękowych, praktyk transkrypcyjnych oraz wpływu czynników kulturowych na sposób transkrypcji danych. Transkrypcja analizowana była jako jeden z gatunków lub wariantów językowych. W LiS zwrócono uwagę na proces zbierania danych $\mathrm{w}$ badaniach etnograficznych: relacji badacza do badanej społeczności, budowania relacji z informatorami oraz komunikowania badacza $\mathrm{w}$ terenie badawczym. Problem relacji badacza do badanych (outsider/insider), autorytetu badacza oraz nienaturalności sytuacji wywiadu były przedmiotem rozważań $w$ L\&C. W pojedynczych przypadkach pojawiały się także metody "egzotyczne": eksperyment, wywiad zogniskowany (np. dotyczący treści programu telewizyjnego). W kilku przypadkach autorzy używali komputerowej analizy korpusów językowych.

\section{Podsumowanie}

Analizy szczegółowe wskazują na kilka cech charakterystycznych dla zachodnich praktyk analizy dyskursu. Po pierwsze, materiałem badań jest najczęściej język mówiony, a sposobem zbierania materiału - badania terenowe (wywiady, etnografia itd.). Oznacza to, że badacz dyskursu nie obcuje wyłącznie z tekstem, ale także z ludźmi i instytucjami. Stawia go to w pozycji wzajemnej zależności z terenem badawczym.

Ta cecha wydaje się być powiązana z kolejnymi: przewagą badań stosowanych, skupieniem się na kontekstach instytucjonalnych (przede wszystkim biznesowym, akademickim i edukacyjnym) oraz przewaga prac empirycznych nad teoretycznymi. W przypadku preferencji dla dyskursu instytucjonalnego istotne może być także to, że łatwiej jest kontrolować kontekst sytuacyjny rozmów, jego granice i elementy, a więc prowadzić badania bardziej przejrzyste metodologicznie.

Praktyczna i empiryczna orientacja jest powiązana z preferencjami pewnego rodzaju kategorii analitycznych. Mając do wyboru alternatywne interpretacje kategorii, autorzy preferują te, które pozwalają na mocne "zakorzenienie" analizy w kontekście społecznym. Najczęściej pojawiają się kategorie związane z porządkowaniem świata społecznego (kategoryzacje), a także tożsamością jako projektem (por. Giddens 2001) oraz kategorie semiotyczne (tworzenie i interpretowanie znaczeń) i pragmatyczne (mówienie jako działanie). Używane kategorie analityczne wskazują, że analiza dyskursu jest uprawiana poprzez stałe wychodzenie poza zdanie i tekst $\mathrm{w}$ stronę kontekstu społecznego. 
Na poziomie teoretycznym zauważalna jest przewaga podejść skupionych na interakcji (m.in. analiza konwersacyjna, etnografia mówienia, socjolingwistyka interakcyjna) i podzielających procesualną wizję świata społecznego. Interesującą cechą zachodnich czasopism dyskursywnych jest ponadto hybrydalność podejść teoretycznych. Wynikać to może z instrumentalnego i pragmatycznego traktowania teorii jako klucza do analizy, a nie przedmiotu badań sui generis. Alternatywnie przypuścić można, że eklektyzm pojęciowy i metodologiczny jest jedynie strukturą powierzchniową, pod którą ukryte są procesy konsolidacji AD.

\section{Bibliografia}

Agha Asif (2003) The Social Life of Cultural Value. „Language and Communication", vol. 23, s. 231-273.

Barth Fredrik i in. (2007) Antropologia. Jedna dyscyplina, cztery tradycje: brytyjska, niemiecka, francuska i amerykańska. Przełożyła Joanna Tegnerowicz. Kraków: Wydawnictwo Uniwersytetu Jagiellońskiego.

Basso Keith H. (1979) Portraits of "The Whiteman": Linguistic Play and Cultural Symbols Among the Western Apache. Cambridge: Cambridge University Press.

Bhatia Vijay K. (1993) Analyzing Genre: Language Use in Professional Settings. London: Longman.

Blommaert Jan (2005) Discourse. A Critical Introduction. Cambridge: Cambridge University Press.

Brinton Laurel L. (2008) Historical Discourse Analysis [w:] Deborah Schiffrin, Deborah Tannen, Heidi E. Hamilton, eds., The Handbook of Discourse Analysis. Oxford: Blackwell, s. 138-160.

Brown Penelope, Levinson Stephen C. (1987) Politeness: Some Universals in Language Usage. Cambridge: Cambridge University Press.

Brown Roger, Gilman Albert (1960) The Pronouns of Power and Solidarity [w:] Thomas A. Sebeok, ed., Style in Language. Cambridge: MIT Press, s. 253-277.
Uzyskany przez nas obraz praktyk AD spreparowany został na podstawie materiału $\mathrm{z}$ czasopism. Nie wykluczamy, że uwzględnienie książek, podręczników, materiałów z obrad konferencyjnych, stron internetowych instytutów badawczych, sylabusów, wniosków grantowych i tak dalej skomplikowałoby go i zmieniło. Jednak wychodząc z założenia, że czasopisma stanowią istotną płaszczyznę upubliczniania wyników badań, sądzimy, iż dokonana przez nas rekonstrukcja może być pomocna zarówno dla zrozumienia zachodnich praktyk $A D$, jak i polskiej specyfiki analiz dyskursywnych

Carter Ronald A., Malmkjær Kirsten (2002) Text linguistics [w:] Kirsten Malmkjær, ed., The Linguistics Encyclopedia. London: Routledge, s. 540-551.

Cots Joseph M. (2006) Discourse Strategies [w:] Philipp Strazny, ed., Encyclopedia of Linguistics. New York: Taylor \& Francis, s. 271-272.

Cutting Joan (2011) Spoken Discourse [w:] Ken Hyland, Brian Paltridge, eds., Continuum Companion to Discourse Analysis. London: Continuum, s. 155-170.

Czyżewski Marek (2005) Dyskurs [w:] Encyklopedia Socjologii. Suplement. Władysław Kwaśniewicz i inni, red. Warszawa: Oficyna Naukowa, s. 50-58.

----- (2008) Elementy i catości. O niektórych dylematach analizy dyskursu [w:] Anna Horolets, red., Analiza dyskursu w socjologii i dla socjologii. Toruń: Adam Marszałek, s. $19-29$.

van Dijk Teun A. (2008) Critical Discourse Analysis [w:] Deborah Schiffrin, Deborah Tannen, Heidi E. Hamilton, eds, The Handbook of Discourse Analysis. London: Blackwell, s. 372-397.

----- (2009) Society and Discourse. How Social Contexts Influence Text and Talk. Cambridge: Cambridge University Press.
Drew Paul (2001) Conversation Analysis [w:] Rajend Mesthrie, ed., Concise Encyclopedia of Sociolinguistics. Oxford: Elsevier, s. 109-116.

Duszak Anna, Fairclough Norman, red., (2008) Krytyczna analiza dyskursu. Interdyscyplinarne podejście do komunikacji społecznej. Kraków: Universitas.

Fairclough Norman (1992) Discourse and Social Change. Cambridge: Polity Press.

----- (2003) Analysing Discourse. Textual Analysis for Social Research. London: Routledge.

----- (2006) Genres in Political Discourse [w:] Keith Brown, ed., Encyclopedia of Language and Linguistics. Oxford: Elsevier, s. 32-38.

Giddens Anthony (2001) Nowoczesność $i$ tożsamość. "Ja" i społeczeństwo w epoce późnej nowoczesności. Przełożyła Alina Szulżyńska. Warszawa: Wydawnictwo Naukowe PWN.

Grzymała-Kazłowska Aleksandra (2004) Socjologicznie zorientowana analiza dyskursu na tle współczesnych badań nad dyskursem. „Kultura i Społeczeństwo”, nr 4, s. 13-34.

Gumperz John (2008) Interactional Sociolinguistics: A Personal Perspective [w:] Deborah Schiffrin, Deborah Tannen, Heidi E. Hamilton, eds., The Handbook of Discourse Analysis. Malden: Blackwell, s. 215-228.

Halliday Michael A. K. (1978) Language as Social Semiotic. London: Edward Arnold.

Harré Rom (2008) The Discursive Turn in Social Psychology [w:] Deborah Schiffrin, Deborah Tannen, Heidi E. Hamilton, eds., The Handbook of Discourse Analysis. London: Blackwell, s. 688-706.

Harré Rom, van Langenhove Luk, eds., (1999) Positioning Theory: Moral Contexts of Intentional Action. Malden: Blackwell.

Hunter Lynette (1990) A Rhetoric of Mass Communication: Collective or Corporate Public Discourse [w:] Richard L. Enos, ed., Oral and Written Communication. Historical Approaches. London: Sage, s. 216-261.

Hymes Dell H. (1996) Ethnography, Linguistics, Narrative Inequality: Target Organ and Modulator of Toxicity. London: Taylor \& Francis.
Ilie Cornelia (2006) Rhetoric, Classical [w:] Keith Brown, ed., Encyclopedia of Language and Linguistics. Oxford: Elsevier, s. 573-579.

Jabłońska Barbara (2006) Krytyczna analiza dyskursu: refleksje teoretyczno-metodologiczne. „Przegląd Socjologii Jakościowej", t. 2, nr 1 [dostęp 2 listopada 2012]. Dostępny $\mathrm{w}$ Internecie: http://www.qualitativesociologyreview. org /PL/archive_pl.php»

Jha Alok (2012) Academic spring: how an angry maths blog sparked a scientific revolution. „Guardian”, 9 kwietnia [dostęp 28 listopada 2012]. Dostępny w Internecie «www.guardian.co.uk/science

Kurcz Ida, Okuniewska Hanna, red., (2011) Język jako przedmiot badań psychologicznych. Psycholingwistyka ogólna ineurolingwistyka. Warszawa: Wydawnictwo Academica, SWPS

Labov William (1966) The Social Stratification of English in New York City. Washington: Center for Applied Linguistics.

Labov William, Waletzky Joshua (1967) Narrative Analysis: Oral Versions of Personal Experience [w:] June Helm, ed. Essays on the Verbal and Visual Arts. Seattle: University of Washington Press, s. 12-44.

Lakoff George, Johnson Mark (1988) Metafory w naszym życiu. Przełożył Tomasz Paweł Krzeszowski. Warszawa: Państwowy Instytut Wydawniczy.

Levinson Stephen C. (2010) Pragmatyka. Przełożyli Tadeusz Ciecierski, Katarzyna Stachowicz. Warszawa: Wydawnictwo Naukowe PWN.

Liddicoat Anthony J. (2007) An Introduction to Conversation Analysis. London: Continuum.

Lisowska-Magdziarz Małgorzata (2006) Analiza tekstu w dyskursie medialnym. Przewodnik dla studentów. Kraków: Wydawnictwo UJ.

Malmkjær Kirsten, ed., (2002) Semantics [w:] The Linguistics Encyclopedia. London: Routledge, s. 455-468.

Myers Greg (1990) Writing Biology: Texts in the Social Construction of Scientific Knowledge. Madison: University of Wisconsin Press.

Narrative Inquiry (2006) Special Issue: Narrative - State of the Art, ed., Michael Bamberg, vol. 16, no. 1. 
Nijakowski Lech (2006) Hermeneutyka i teoria dyskursu [w:] Aleksandra Jasińska-Kania i in., red., Wspótczesne teorie socjologiczne, t. 2. Warszawa: Scholar, s. 995-1000.

Norrick Neal R. (2008) Discourse and Semantics [w:] Deborah Schiffrin, Deborah Tannen, Heidi E. Hamilton, eds., The Handbook of Discourse Analysis. London: Blackwell, s. 76-99.

Ogden Charles K., Richards Ivor A. (1923) The Meaning of Meaning. London: Routledge.

Ong Walter J. (1982) Orality and Literacy. The Technologizing of the World. London, New York: Menthuen.

Pawliszak Piotr, Rancew-Sikora Dorota (2012) Wprowadzenie do socjologicznej analizy dyskursu. „Studia Socjologiczne", nr 1, s. 5-15.

Pękala Justyna (2009) Mechanizm peer review na przykładzie polskich czasopism naukowych [komputeropis]. Instytut Socjologii Uniwersytetu Warszawskiego.

Przepiórkowski Adam i in., red., (2012) Narodowy Korpus Jezzyka Polskiego. Warszawa: Wydawnictwo Naukowe PWN.

Rancew-Sikora Dorota (2007) Analiza konwersacyjna jako metoda badania rozmów codziennych. Warszawa: Trio.

Rapley Tim (2010) Analiza konwersacji, dyskursu i dokumentów. Przełożyła Anna Gąsior-Niemiec. Warszawa: Wydawnictwo Naukowe PWN.

Reisigl Martin (2006) Rhetorical Tropes in Political Discourse [w:] Keith Brown, ed., Encyclopedia of Language and Linguistics. Oxford: Elsevier, s. 597-604

----- (2011) Analiza retoryki politycznej [w:] Ruth Wodak, Michał Krzyżanowski, red. Jakościowa analiza dyskursu w naukach społecznych. Warszawa: Łośgraf, s. 151-183.

Ricoeur Paul (1992) Filozofia osoby. Przełożyła Małgorzata Frankiewicz. Kraków: Wydawnictwo PAT.

Rose Gillian (2010) Interpretacja materiałów wizualnych. Przełożyła Ewa Klekot. Warszawa: Wydawnictwo Naukowe PWN.

Sarangi Srikant (2011) Editorial: contextualizing Gumperz. „Text and Talk”, vol. 31, no. 4, s. 375-380.
Schegloff Emanuel A. (1972) Notes on a Conversational Practice: Formulating Place [w:] David Sudnow, ed., Studies in Social Interaction. New York: Free Press, s. 75-119.

----- (1992) Repair after Next Turn. „American Journal of Sociology", vol. 97, no. 5, s. 1295-1345.

Schneider Klaus (2005) Pragmatics [w:] Philipp Strazny, ed., Encyclopedia of Linguistics. New York: Taylor \& Francis, s. 869-872.

Sennet Richard (2006) Korozja charakteru. Osobiste konsekwencje pracy w nowym kapitalizmie. Przełożyli Jan Dziergowski i Łukasz Mikołajewski. Warszawa: Muza.

Shuy Roger W. (2008) Discourse Analysis in Legal Context [w:] Deborah Schiffrin, Deborah Tannen, Heidi E. Hamilton, eds., Handbook of Discourse Analysis. London: Blackwell, s. 437-452.

Stachowiak Jerzy (2012) Analiza relacji władzy w konkurencyjnych perspektywach Noama Chomsky'ego i Michela Foucault. „Studia Socjologiczne”, nr 1 (204), s. 93-110.

Stubbs Michael (2008) Computer Assisted Text and Corpus Analysis: Lexical Cohesion and Communicative Competence [w:] Deborah Schiffrin, Deborah Tannen, Heidi E. Hamilton, eds., The Handbook of Discourse Analysis. London: Blackwell, s. 304-320.

Taverniers Miriam (2006) Grammatical Metaphor and Lexical Metaphor: Different Perspectives on Semantic Variation. „Neophilologus", vol. 90, no. 2, s. 321-332.

Thompson Geoff, Hunston Susan (2006) Evaluation in Text [w:] Keith Brown, ed. Encyclopedia of Language and Linguistics. Oxford: Elsevier, s. 305-312.

Trudgill Peter (1986) Dialects in contact. Oxford: Blackwell.

Trutkowski Cezary (2004) Wybór czy konieczność - o potrzebie wykorzystania analizy dyskursu w socjologii. „Kultura i Społeczeństwo", nr 4, s. 35-50.

Trzebiński Jerzy, red., (2002) Narracja jako sposób rozumienia świata. Gdańsk: GWP.

Wetherell Margaret (2008) Themes in Discourse Research The Case of Diana [w:] Margaret Wetherell, Stephanie Tylor, Yates Simeon J., eds., Discourse Theory and Practice. A Reader. London: Sage, s. 14-28.
Widdowson Henry (1995) Discourse analysis: A critical view. „Language and Literature”, no. 4, s. 157-172.

Wodak Ruth (2011a) Wstęp: badania nad dyskursem-ważne pojeccia i terminy [w:] Ruth Wodak, Michał Krzyżanowski, red., Jakościowa analiza dyskursu w naukach społecznych. Warszawa: Łośgraf, s. 11-48.

---- (2011b) Critical Discourse Analysis [w:] Ken Hyland, Brian Paltridge, eds., Continuum Companion to Discourse Analysis. London: Continuum, s. 38-53.
Wodak Ruth, Krzyżanowski Michał, red., (2011) Jakościowa analiza dyskursu w naukach społecznych. Warszawa: Łośgraf.

Yule George (1996) Pragmatics. Oxford: Oxford University Press.

Zarycki Tomasz (2012) Poszerzajac kontekst: ku krytycznej socjologii językoznawstwa. „Studia Socjologiczne”, $\mathrm{nr} 1$ (204), s. 57-73.

\section{Cytowanie}

Bielecka-Prus Joanna, Horolets Anna (2013) Rekonstrukcja praktyk analizy dyskursu na podstawie wybranych anglojezycznych czasopism dyskursywnych. „Przegląd Socjologii Jakościowej”, t. 9, nr 1, s. 152-185 [dostęp dzień, miesiąc, rok]. Dostępny w Internecie: «www.przegladsocjologiijakosciowej.org».

\section{Reconstruction of discourse analytical practices on the basis of discourse analysis journals' abstracts}

Abstract: The article pursues an exploratory goal of reconstructing discourse analytical practices through the research on the content of abstracts that appeared in discourse analysis-centred journals ("Language in Society," "Discourse Studies," "Discourse and Society," “Language and Communication," "Text and Talk") published in English. The selected journals have a high Impact Factor and thus, significantly influence the major methodological trends within discourse analysis. The frequency with which the various types of content, i.e., types of empirical material (e.g., spoken and written discourse) and subject matter (institutional, everyday, media or internet interactions), as well as theoretical approaches and analytical categories, appear has been measured. Detailed analysis of both the journals' diversification and trends common to all journals has allowed to draw tentative generalizations concerning the practices of discourse analysis in the English speaking world. The distinguishing features of these practices are: concentration on interaction, interest in institutional contexts and spoken communication, as well as applied research, to name a few.

Keywords: discourse analysis, research practices, peer-reviewed journals, abstracts, empirical material, object of research, theoretical approaches, methods, analytical categories 